\title{
Perfluorocarbons in the global atmosphere: tetrafluoromethane, hexafluoroethane, and octafluoropropane
}

\author{
J. Mühle ${ }^{1}$, A. L. Ganesan ${ }^{2}$, B. R. Miller ${ }^{1, *}$, P. K. Salameh ${ }^{1}$, C. M. Harth ${ }^{1}$, B. R. Greally ${ }^{3}$, M. Rigby ${ }^{2}$, L. W. Porter ${ }^{* *}$, , \\ L. P. Steele ${ }^{4}$, C. M. Trudinger ${ }^{4}$, P. B. Krummel ${ }^{4}$, S. O'Doherty ${ }^{3}$, P. J. Fraser ${ }^{4}$, P. G. Simmonds ${ }^{3}$, R. G. Prinn ${ }^{2}$, and \\ R. F. Weiss ${ }^{1}$ \\ ${ }^{1}$ Scripps Institution of Oceanography, University of California, San Diego, 9500 Gilman Drive, La Jolla, \\ CA 92093-0244, USA \\ ${ }^{2}$ Center for Global Change Science, Massachusetts Institute of Technology, 77 Massachusetts Ave, Building 54-1312, \\ Cambridge, MA 02139, USA \\ ${ }^{3}$ School of Chemistry, University of Bristol, Cantock's Close, Bristol, BS8 1TS, UK \\ ${ }^{4}$ Centre for Australian Weather and Climate Research/CSIRO Marine and Atmospheric Research/CSIRO Light Metals \\ Flagship, Private Bag No. 1, Aspendale, Victoria 3195, Australia \\ " now at: Cooperative Institute for Research in Environmental Sciences, University of Colorado, Box 216 UCB, Boulder, \\ CO 80309-0216, USA \\ ** formerly at: Centre for Australian Weather and Climate Research/Australian Government Bureau of Meteorology, \\ P. O. Box 1636, Melbourne, Victoria 3001, Australia \\ $\dagger$ deceased (7 December 2007)
}

Received: 12 February 2010 - Published in Atmos. Chem. Phys. Discuss.: 9 March 2010

Revised: 26 May 2010 - Accepted: 26 May 2010 - Published: 9 June 2010

\begin{abstract}
We present atmospheric baseline growth rates from the 1970 s to the present for the longlived, strongly infrared-absorbing perfluorocarbons (PFCs) tetrafluoromethane $\left(\mathrm{CF}_{4}\right)$, hexafluoroethane $\left(\mathrm{C}_{2} \mathrm{~F}_{6}\right)$, and octafluoropropane $\left(\mathrm{C}_{3} \mathrm{~F}_{8}\right)$ in both hemispheres, measured with improved accuracies $(\sim 1-2 \%)$ and precisions $(<0.3 \%$, or $<0.2 \mathrm{ppt}$ (parts per trillion dry air mole fraction), for $\mathrm{CF}_{4} ;<1.5 \%$, or $<0.06 \mathrm{ppt}$, for $\mathrm{C}_{2} \mathrm{~F}_{6} ;<4.5 \%$, or $<0.02 \mathrm{ppt}$, for $\mathrm{C}_{3} \mathrm{~F}_{8}$ ) within the Advanced Global Atmospheric Gases Experiment (AGAGE). Pre-industrial background values of $34.7 \pm 0.2$ ppt $^{-C_{4}}$ and $0.1 \pm 0.02$ ppt $\mathrm{C}_{2} \mathrm{~F}_{6}$ were measured in air extracted from Greenland ice and Antarctic firn. Anthropogenic sources are thought to be primary aluminum production $\left(\mathrm{CF}_{4}, \mathrm{C}_{2} \mathrm{~F}_{6}, \mathrm{C}_{3} \mathrm{~F}_{8}\right)$, semiconductor production $\left(\mathrm{C}_{2} \mathrm{~F}_{6}, \mathrm{CF}_{4}, \mathrm{C}_{3} \mathrm{~F}_{8}\right)$ and refrigeration use $\left(\mathrm{C}_{3} \mathrm{~F}_{8}\right)$. Global
\end{abstract}

emissions calculated with the AGAGE 2-D 12-box model are significantly higher than most previous emission estimates. The sum of $\mathrm{CF}_{4}$ and $\mathrm{C}_{2} \mathrm{~F}_{6}$ emissions estimated from aluminum production and non-metal production are lower than observed global top-down emissions, with gaps of $\sim 6 \mathrm{Gg} / \mathrm{yr}$ $\mathrm{CF}_{4}$ in recent years. The significant discrepancies between previous $\mathrm{CF}_{4}, \mathrm{C}_{2} \mathrm{~F}_{6}$, and $\mathrm{C}_{3} \mathrm{~F}_{8}$ emission estimates and observed global top-down emissions estimated from AGAGE measurements emphasize the need for more accurate, transparent, and complete emission reporting, and for verification with atmospheric measurements to assess the emission sources of these long-lived and potent greenhouse gases, which alter the radiative budget of the atmosphere, essentially permanently, once emitted.

\section{Correspondence to: J. Mühle}

(jens@gaslab.ucsd.edu) 
Table 1. Lifetimes and global warming potentials of $\mathrm{CF}_{4}, \mathrm{C}_{2} \mathrm{~F}_{6}$, and $\mathrm{C}_{3} \mathrm{~F}_{8}$.

\begin{tabular}{llllll}
\hline \multirow{2}{*}{ Formula } & Name & $\begin{array}{l}\text { Lifetime } \\
\text { years }\end{array}$ & \multicolumn{3}{c}{ Global Warming Potential (GWP) } \\
& & & $\left(\mathrm{SAR}^{\mathrm{a}}\right)$ & $\left(\mathrm{AR} 4^{\mathrm{b}}\right)$ & $(\mathrm{AR} 4)$ \\
$\mathrm{CF}_{4}$ & $\mathrm{PFC}-14$ & 50000 & 6500 & 7390 & 11200 \\
$\mathrm{C}_{2} \mathrm{~F}_{6}$ & $\mathrm{PFC}-116$ & 10000 & 9200 & 12200 & 18200 \\
$\mathrm{C}_{3} \mathrm{~F}_{8}$ & PFC-218 & 2600 & 7000 & 8830 & 12500 \\
\hline
\end{tabular}

a IPCC Second Assessment Report;

b IPCC Fourth Assessment Report.

\section{Introduction}

The perfluorocarbons (PFCs) tetrafluoromethane $\left(\mathrm{CF}_{4}\right.$, $\mathrm{PFC}$ 14), hexafluoroethane $\left(\mathrm{C}_{2} \mathrm{~F}_{6}\right.$, PFC-116), and octafluoropropane $\left(\mathrm{C}_{3} \mathrm{~F}_{8}\right.$, PFC-218) are among the longest-lived and most potent greenhouse gases (GHGs) regulated under the Kyoto Protocol of the United Nations Framework Convention on Climate Change (UNFCCC). $\mathrm{CF}_{4}$ is the most abundant PFC with an atmospheric lifetime of at least 50000 years and a global warming potential $\left(\mathrm{GWP}_{100}\right)$ of at least 7390 (100-yr horizon) (Cicerone, 1979; Ravishankara et al., 1993; Morris et al., 1995; Jain et al., 2000; Hurley et al., 2005; Clerbaux et al., 2007; Forster et al., 2007). $\mathrm{C}_{2} \mathrm{~F}_{6}$ and $\mathrm{C}_{3} \mathrm{~F}_{8}$ have lifetimes of at least 10000 and 2600 years and $\mathrm{GWP}_{100}$ s of at least 12200 and 8830 , respectively (see Table 1).

Atmospheric $\mathrm{CF}_{4}$ was first observed by Gassmann (1974) in krypton obtained by fractional air distillation. Soon $\mathrm{CF}_{4}$ and $\mathrm{C}_{2} \mathrm{~F}_{6}$ were found to be ubiquitous in the troposphere (Rasmussen et al., 1979; Penkett et al., 1981) and stratosphere (Goldman et al., 1979; Fabian et al., 1981). The less abundant $\mathrm{C}_{3} \mathrm{~F}_{8}$ was just recently found in the atmosphere (Culbertson et al., 2000).

$\mathrm{CF}_{4}$, and to a smaller degree $\mathrm{C}_{2} \mathrm{~F}_{6}$, are released during primary aluminum $(\mathrm{Al})$ production at the anode when the feed of aluminum oxide to the electrolysis cell is restricted ("anode effects") (Holliday and Henry, 1959; Penkett et al., 1981; Taberaux, 1994; International (Primary) Aluminium Institute, 1996, 2009b). Gassmann (1974) first suggested that there is also a natural $\mathrm{CF}_{4}$ source based on mass spectrometric evidence in gas extracted from fluorite minerals by Kranz (1966). Harnisch et al. (1996a, 2000) and Harnisch and Eisenhauer (1998) found elevated $\mathrm{CF}_{4}$ in fluorite and granite minerals and in Russian natural gas, pointing to a lithospheric source, and concluded that lithosphere emissions could explain the natural $\mathrm{CF}_{4}$ background, even though anthropogenic fluxes were $10^{3}-10^{5}$ times higher and rising. Deeds et al. (2008) provided the first evidence for this lithospheric $\mathrm{CF}_{4}$ flux based on dissolved $\mathrm{CF}_{4}$ in groundwaters. From stratospheric profiles Fabian et al. (1987) concluded that natural sources contributed $43.5 \mathrm{ppt}$ (parts per trillion) to the dry air mole fraction of atmospheric $\mathrm{CF}_{4}$. Later Harnisch et al. (1996a, b) derived natural abundances of $39 \pm 6 \mathrm{ppt} \mathrm{CF}_{4}$ from old air trapped in ice cores and glass vessels, and $44 \mathrm{ppt}$ from stratospheric air dated by sulfur hexafluoride $\left(\mathrm{SF}_{6}\right)$ abundance. Khalil et al. (2003) estimated a natural abundance of 40-43.8 ppt $\mathrm{CF}_{4}$ and Worton et al. (2007) obtained $34 \pm 1$ ppt $\mathrm{CF}_{4}$ from firn air. Despite this evidence of a large natural $\mathrm{CF}_{4}$ abundance, some uncertainty in the correct value remained (Table 2). No natural $\mathrm{C}_{2} \mathrm{~F}_{6}$ or $\mathrm{C}_{3} \mathrm{~F}_{8}$ sources have been found (Harnisch, 2000) and natural abundances have been assumed to be insignificant (Fabian et al., 1987; Harnisch et al., 1996b; Khalil et al., 2003) or at most 0.3 ppt for $\mathrm{C}_{2} \mathrm{~F}_{6}$ (Worton et al., 2007).

Since the $1980 \mathrm{~s} \mathrm{CF}_{4}, \mathrm{C}_{2} \mathrm{~F}_{6}$, and $\mathrm{C}_{3} \mathrm{~F}_{8}$ have been used increasingly in semiconductor and other electronics manufacture for cleaning, plasma etching, and chemical vapor deposition, leading to significant emissions due to incomplete conversion to fluorine plasma followed by release into the atmosphere (Cook, 1995; Victor and MacDonald, 1999; Harnisch, 2000; Tsai et al., 2002; Khalil et al., 2003). Khalil et al. (2003) and Worton et al. (2007) estimated the contributions from $\mathrm{Al}$ production and semiconductor/electronics manufacture to $\mathrm{CF}_{4}$ and $\mathrm{C}_{2} \mathrm{~F}_{6}$ emissions separately, but such detailed apportioning is difficult due to large uncertainties in the magnitude and temporal evolution of emission factors from $\mathrm{Al}$ production. Other potential anthropogenic sources, believed to be small, could include the production of fluorocarbons, fluorochemicals, and fluorine, the combustion of fluorocarbons and rocket fuels, the separation of uranium isotopes, and the use of fluorspar in steelmaking (Cicerone, 1979; Cook, 1995). So far no evidence for volcanic $\mathrm{CF}_{4}$ emissions has been found (Rasmussen et al., 1979; Penkett et al., 1981; Symonds et al., 1988; Harnisch and Eisenhauer, 1998).

For the Northern Hemisphere (NH) Harnisch et al. (1995, 1996b, 1999) and Khalil et al. (2003) reconstructed $\mathrm{CF}_{4}$ trends of $\sim 1.1 \mathrm{ppt} / \mathrm{yr}$ from 1978 until $\sim 1990$ and reduced trends of $\sim 0.7-1.0 \mathrm{ppt} / \mathrm{yr}$ thereafter, most likely caused by lower frequency and duration of "anode effects" due to measures by the $\mathrm{Al}$ industry to increase efficiency and to reduce PFC emissions (Taberaux, 1994; International (Primary) 
Table 2. Estimates of natural portions of accumulated atmospheric $\mathrm{CF}_{4}, \mathrm{C}_{2} \mathrm{~F}_{6}$, and $\mathrm{C}_{3} \mathrm{~F}_{8}$.

\begin{tabular}{|c|c|c|c|}
\hline & $\mathrm{CF}_{4}(\mathrm{ppt})$ & $\mathrm{C}_{2} \mathrm{~F}_{6}(\mathrm{ppt})$ & $\mathrm{C}_{3} \mathrm{~F}_{8}(\mathrm{ppt})$ \\
\hline This work & $34.66 \pm 0.16(\text { Greenland })^{\mathrm{a}}$ & $0.1 \pm 0.02$ & $<0.02$ (not detected) \\
\hline This work & 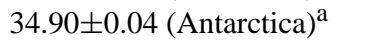 & & \\
\hline This work & $34.7 \pm 0.2(\text { overall average })^{\mathrm{a}}$ & & \\
\hline Worton et al. (2007) & $34 \pm 1$ & $<0.3$ & \\
\hline Khalil et al. (2003) & $40,43.8$ & all anthropogenic & all anthropogenic \\
\hline Harnisch et al. (1996b) & $\sim 44$ & all anthropogenic & \\
\hline Harnisch et al. (1996a) ${ }^{b}$ & $39 \pm 6$ & & \\
\hline Fabian et al. $(1987)^{\mathrm{b}}$ & $\sim 43.5$ & all anthropogenic & \\
\hline
\end{tabular}

${ }^{\text {a }}$ Eleven air samples extracted from ancient Greenland ice $(\sim 11-19 \mathrm{kyr}$ BP) and two old firn samples from Antarctica $(\sim 1910)$ were measured.

${ }^{\mathrm{b}}$ Based on $\mathrm{SF}_{6}$ dated stratospheric air.

Table 3. $\mathrm{CF}_{4}$ measurement precisions, scale accuracies, sample origins, and tropospheric trends.

\begin{tabular}{|c|c|c|c|c|c|c|c|}
\hline \multirow[b]{2}{*}{ This work } & \multirow{2}{*}{$\begin{array}{l}\text { precision } \\
0.06-0.3 \%\end{array}$} & \multirow{2}{*}{$\begin{array}{l}\text { accuracy, scale } \\
\sim 1-2 \%, \text { SIO-2005 }\end{array}$} & \multirow{2}{*}{$\begin{array}{l}\text { sample origin } \\
\text { troposphere }\end{array}$} & \multicolumn{2}{|c|}{$\mathrm{NH}$ rise rate $(\mathrm{ppt} / \mathrm{yr})$} & \multicolumn{2}{|c|}{$\mathrm{SH}$ rise rate $(\mathrm{ppt} / \mathrm{yr})$} \\
\hline & & & & 1973-1991 & $1.080 \pm 0.007$ & 1978-1992 & $1.067 \pm 0.013$ \\
\hline This work & $0.05-0.2 \mathrm{ppt}$ & & troposphere & 1993-2008 & $0.686 \pm 0.002$ & 1994-2008 & $0.702 \pm 0.001$ \\
\hline Khalil and Rasmussen (1985) & - & - & troposphere & - & - & 1978-1984 & $0.8-2$ \\
\hline Harnisch et al. (1995) & $\pm 5 \%$ b & $\pm 10 \%$, MPAE $86^{\mathrm{b}}$ & stratosphere $^{\mathrm{a}}$ & 1978-1994 & $0.97 \pm 0.07^{\mathrm{a}}$ & a & same as $\mathrm{NH}^{\mathrm{a}}$ \\
\hline Harnisch et al. (1996b) & $\pm 5 \% \mathrm{~b}$ & $\pm 10 \%$, MPAE $86^{\mathrm{b}}$ & stratosphere $^{\mathrm{a}}$ & 1982-1995 & $1.00 \pm 0.05^{\mathrm{a}}$ & a & same as $\mathrm{NH}^{\mathrm{a}}$ \\
\hline Harnisch et al. (1999) & $\sim \pm 2.4 \mathrm{ppt}^{\mathrm{b}}$ & MPAE $86^{\mathrm{b}}$ & troposphere & $1978-1990$ & $1.07 \pm 0.14$ & - & - \\
\hline Harnisch et al. (1999) & & & troposphere & 1992-1998 & $0.72 \pm 0.11$ & - & - \\
\hline Khalil et al. $(2003)^{\mathrm{c}}$ & $\pm 1 \mathrm{ppt}$ & $\pm 10 \%$, MPAE $86^{\mathrm{e}}$ & troposphere & 1978-1986 & $1.1 \pm 0.2$ & - & - \\
\hline Khalil et al. $(2003)^{\mathrm{c}}$ & & & troposphere & 1986-1997 & $0.85 \pm 0.15$ & 1994-1997 & $0.29 \pm 0.31^{\mathrm{c}}$ \\
\hline Worton et al. (2007) & $\sim 1-2 \mathrm{ppt}$ & $\pm 10 \mathrm{ppt}, \pm 13.9 \%$, UEA & firn & $1955-2003$ & $\sim 0.8^{\mathrm{d}}$ & $1955-2003$ & $\sim 0.8^{\mathrm{d}}$ \\
\hline
\end{tabular}

a Global tropospheric trend inferred from $\mathrm{SF}_{6}$ dated stratospheric air.

b Fabian et al. (1987) reported precisions of 5-15\% and accuracies of $\pm 10 \%$ for MPAE 86 . Harnisch and Eisenhauer (1998) reported accuracies of $<5 \%$.

${ }^{\mathrm{c}}$ Khalil et al. (2003) scaled data by 0.8 to agree with the MPAE 86 scale. SH rise rate based on an error weighted linear fit of the Khalil et al. (2003) data.

${ }^{\mathrm{d}}$ Based on air extracted from firn in the NH and SH and a firn model Worton et al. (2007) report a global doubling (from 40 to 78 ppt) from 1955 to 2003.

e See also Culbertson et al. (2000).

Note that Aoki and Makide (2004) reported excellent precision of $\sim 1 \%$ for tropospheric $\mathrm{CF}_{4}$ measurements based on $\mathrm{CF}_{4} /{ }^{80} \mathrm{Kr}$ ratios, but the method is complicated due to uncertainties in the tropospheric ${ }^{80} \mathrm{Kr}$ abundance (see Sect. 4.1.1).

Aluminium Institute, 1996, 2009b). For the Southern Hemisphere (SH) a general increase in $\mathrm{CF}_{4}$ has also been shown, but measurements were sparser and uncertainties were larger (Table 3). Corresponding stratospheric increases in $\mathrm{CF}_{4}$ were observed (Zander et al., 1996; Zhou et al., 1998; Rinsland et al., 2006). Small $\mathrm{C}_{2} \mathrm{~F}_{6}$ increases before the 1980 s were reconstructed by Worton et al. (2007) from firn air measurements, followed by a strong increase to $\sim 0.07-0.09 \mathrm{ppt} / \mathrm{yr}$ from the 1980s to the early 2000s (Harnisch et al., 1995; 1996b; Khalil et al., 2003; Worton et al., 2007) (Table 4), probably due to increased emissions from the semiconductor industry and $\mathrm{Al}$ production. For $\mathrm{C}_{3} \mathrm{~F}_{8}$ continuously increasing tropospheric trends from the 1970s to the mid-1990s have been reported, probably due to increasing use in the semicon- ductor industry (Khalil et al., 2003; Culbertson et al., 2004) (Table 5), but the scatter in the measurements is large.

In the Emission Database for Global Atmospheric Research (EDGAR) v4 (2009) $\mathrm{CF}_{4}$ and $\mathrm{C}_{2} \mathrm{~F}_{6}$ emissions are mostly attributed to the production of metals (mostly Al production), followed by emissions from semiconductor/electronics manufacture, the latter gaining dominance for $\mathrm{C}_{2} \mathrm{~F}_{6}$ in the mid-1990s. $\mathrm{C}_{3} \mathrm{~F}_{8}$ emissions are largely attributed to refrigeration/air conditioning use and semiconductor/electronics manufacture. Unfortunately, as we discuss further below, the EDGAR database does not provide all details necessary to understand how their PFC emission estimates are calculated or apportioned. 
Table 4. $\mathrm{C}_{2} \mathrm{~F}_{6}$ measurement precisions, scale accuracies, sample origins, and tropospheric trends.

\begin{tabular}{|c|c|c|c|c|c|c|c|}
\hline \multirow[b]{2}{*}{ This work } & \multirow{2}{*}{$\begin{array}{l}\text { precision } \\
0.5-1.5 \%\end{array}$} & \multirow{2}{*}{$\begin{array}{l}\text { accuracy, scale } \\
\sim 1-2 \%, \text { SIO-2007 }\end{array}$} & \multirow{2}{*}{$\begin{array}{l}\text { sample origin } \\
\text { troposphere }\end{array}$} & \multicolumn{2}{|c|}{$\mathrm{NH}$ rise rate (ppt/yr) } & \multicolumn{2}{|c|}{$\mathrm{SH}$ rise rate (ppt/yr) } \\
\hline & & & & 1973-1996 & $\sim 0.084$ & 1978-1997 & $\sim 0.087 \pm 0.001$ \\
\hline This work & $0.02-0.06 \mathrm{ppt}$ & & troposphere & 1998-2004 & $\sim 0.118$ & 1998-2004 & $\sim 0.119 \pm 0.001$ \\
\hline This work & & & troposphere & 2004-2008 & $\sim 0.090$ & 2005-2008 & $\sim 0.099 \pm 0.002$ \\
\hline Harnisch et al. (1995) & $\pm 10 \%^{\mathrm{b}}$ & $\pm 10 \%^{\mathrm{b}}$, MPAE 86 & stratosphere $^{\mathrm{a}}$ & $1980-1995$ & $0.086 \pm 0.005^{\mathrm{a}}$ & a & a \\
\hline Harnisch et al. (1996b) & $\pm 10 \% \mathrm{~b}$ & $\pm 10 \%$ b, MPAE 86 & stratosphere $^{\mathrm{a}}$ & $1982-1995$ & $0.084 \pm 0.005^{\mathrm{a}}$ & $\mathrm{a}$ & a \\
\hline Khalil et al. (2003) & $\sim \pm 0.05 \mathrm{ppt}$ & $\pm 10 \%^{\mathrm{c}}$, MPAE $86^{\mathrm{d}}$ & troposphere & 1978-1986 & $0.07 \pm 0.01$ & - & - \\
\hline Khalil et al. (2003) & & & troposphere & 1987-1997 & $0.09 \pm 0.015$ & 1994-1997 & $0.072 \pm 0.019^{\mathrm{d}}$ \\
\hline Worton et al. (2007) & $\pm 0.4-2 \mathrm{ppt}$ & $\pm 10 \%, \mathrm{UEA}$ & firn & $1940-2003$ & $\sim$ factor $10^{\mathrm{e}}$ & $1940-2003$ & $\sim$ factor $10^{\mathrm{e}}$ \\
\hline
\end{tabular}

a Tropospheric trend inferred from $\mathrm{SF}_{6}$ dated stratospheric air.

b Fabian et al. $(1981 ; 1987)$ reported precisions of $\pm 10-15 \%$ and accuracies of $\pm 10 \%$ (MPAE 86 ) for stratospheric measurements.

c See also Culbertson et al. (2000).

${ }^{\mathrm{d}}$ Khalil et al. (2003) scaled data to agree with the MPAE 86 scale. SH rise rate based on an error weighted linear fit of the Khalil et al. (2003) data.

e Worton et al. (2007) state an increase by a factor of $\sim 10$ (from 0.3 to $2.9 \mathrm{ppt}$ ) with a gradually increasing trend.

Table 5. $\mathrm{C}_{3} \mathrm{~F}_{8}$ measurement precisions, scale accuracies, sample origins, and tropospheric trends.

\begin{tabular}{llllllll}
\hline & precisions & accuracies, scale & sample origin & \multicolumn{2}{c}{ NH rise rate $(\mathrm{ppt} / \mathrm{yr})$} & \multicolumn{2}{c}{ SH rise rate $(\mathrm{ppt} / \mathrm{yr})$} \\
\hline This work & $1.5-4.5 \%$, & $\sim 1-2 \%$, SIO-2007 & troposphere & $1973-1989$ & $0.0062 \pm 0.0004$ & $1978-1995$ & $0.0066 \pm 0.0002$ \\
This work & $0.007-0.020 \mathrm{ppt}$ & & troposphere & $1996-2000$ & $0.024 \pm 0.002$ & $1996-2001$ & $0.024 \pm 0.001$ \\
This work & & & troposphere & $2003-2007$ & $0.023 \pm 0.001$ & $2001-2004$ & $0.033 \pm 0.003$ \\
This work & & & troposphere & $2007-2008$ & $0.015 \pm 0.001$ & $2004-2008$ & $0.024 \pm 0.002$ \\
Khalil et al. (2003) & $0.007 \mathrm{ppt}$ & $\pm 10 \% \mathrm{~b}$ & troposphere & $1978-1986$ & $0.0034 \pm 0.0011$ & \\
Khalil et al. (2003) & & & troposphere & $1987-1997$ & $0.009 \pm 0.002$ & $1994-1997$ & $0.014 \pm 0.003^{\mathrm{a}}$ \\
Culbertson et al. (2004) & $0.014 \mathrm{ppt}$ & $\pm 10 \%$ & troposphere & $1978-1998$ & increasing & \\
Culbertson et al. (2004) & & & troposphere & $1986-1998$ & $\sim 0.012$ & $1992-1998$ & $\sim 0.012$ \\
\hline
\end{tabular}

${ }^{a}$ SH trend based on an error weighted linear fit of the Khalil et al. (2003) data.

${ }^{\mathrm{b}}$ See also Culbertson et al. (2000).

For $\mathrm{CF}_{4}$ and $\mathrm{C}_{2} \mathrm{~F}_{6}$, several sink processes have been investigated, including photolysis by vacuum ultraviolet radiation, reactions with oxygen and hydrogen atoms, vibrationally excited $\mathrm{OH}$, and ions in the stratosphere and above, but it seems that the lifetimes are mainly limited by thermal destruction during high-temperature combustion at ground level (Cicerone, 1979; Ravishankara et al., 1993; Morris et al., 1995). Similar sinks can be expected for $C_{3} F_{8}$. Due to their long atmospheric lifetimes, PFC emissions can permanently alter the radiative budget of the atmosphere (Cicerone, 1979; Abrahamson, 1992; Victor and MacDonald, 1999), and careful atmospheric long-term observations are necessary to quantity emissions.

Khalil et al. (2003) addressed substantial differences in the calibration scales of up to $20 \%$ for $\mathrm{CF}_{4}$ and $64 \%$ for $\mathrm{C}_{2} \mathrm{~F}_{6}$ by multiplying their own and several other published $\mathrm{CF}_{4}$ and $\mathrm{C}_{2} \mathrm{~F}_{6}$ data sets by factors to bring them into reasonable agreement with data on the MPAE 86 calibration scale (e.g., Harnisch et al., 1995, 1996b, 1999). Moreover, the MPAE 86 and other PFC scales have stated uncertainties of $\sim \pm 10 \%$ (Tables 3, 4, and 5), compared to 1-2\% typically achieved for other halogenated trace gases (e.g., Maiss et al., 1996; Prinn et al., 2000). For $\mathrm{CF}_{4}$, the most abundant PFC, substantial analytical difficulties have prevented precisions better than several percent until now (Fig. 1, Table 3), compared to 0.04$0.5 \%$ typically achieved for many halogenated trace gases (e.g., Maiss et al., 1996; Prinn et al., 2000). Clearly, more accurate PFC calibration scales and a more precise $\mathrm{CF}_{4}$ measurement method were needed to characterize the impacts of these long-lived and potent GHGs.

Here we present measurements of $\mathrm{CF}_{4}, \mathrm{C}_{2} \mathrm{~F}_{6}$, and $\mathrm{C}_{3} \mathrm{~F}_{8}$ with significantly improved accuracies of $\sim 1-2 \%$ on calibration scales developed for the Advanced Global Atmospheric Gases Experiment (AGAGE) program using new instrumentation which achieves excellent precisions for all three PFCs. We determine long-term baseline growth rates and interhemispheric gradients for $\mathrm{CF}_{4}, \mathrm{C}_{2} \mathrm{~F}_{6}$, and $\mathrm{C}_{3} \mathrm{~F}_{8}$ over three decades, based on measurements of the Cape Grim Air Archive (CGAA) for the Southern Hemisphere, archived air samples from various sources for the Northern Hemisphere, and several years of continuous atmospheric measurements at five remote AGAGE stations. The pre-industrial 
background of $\mathrm{CF}_{4}$ is determined precisely from air extracted from Greenland ice and Antarctic firn. Global inversions of these measurements with the AGAGE 2-D 12-box model are used to estimate the global source strength of $\mathrm{CF}_{4}, \mathrm{C}_{2} \mathrm{~F}_{6}$, and $\mathrm{C}_{3} \mathrm{~F}_{8}$ over the last three decades. We compare these measurement-based, top-down global source strengths with previous emission estimates and reveal significant discrepancies, underlining the need for more accurate, transparent, and complete emission reporting and verification with atmospheric measurements.

\section{Experimental methods}

\subsection{Instrumentation and calibration}

$\mathrm{CF}_{4}, \mathrm{C}_{2} \mathrm{~F}_{6}, \mathrm{C}_{3} \mathrm{~F}_{8}$, and $\sim 35$ other halogenated compounds are measured by AGAGE in $2 \mathrm{~L}$ air samples with the "Medusa" cryogenic preconcentration system with gas chromatograph (GC, Agilent 6890) and quadrupole mass selective detector (MSD, Agilent 5973) (Miller et al., 2008). For this work, data from seven Medusa GC/MSD instruments were used. The instrument at the Scripps Institution of Oceanography (SIO, La Jolla, $33^{\circ} \mathrm{N}, 117^{\circ} \mathrm{W}$, California) serves as the primary calibration instrument for the AGAGE network. Archived air samples (see Sect. 2.2) were measured at SIO and at the Commonwealth Scientific and Industrial Research Organisation Marine and Atmospheric Research (CSIRO, Aspendale, Australia). Routine ambient $\mathrm{C}_{2} \mathrm{~F}_{6}$ and $\mathrm{C}_{3} \mathrm{~F}_{8}$ measurements began in October 2003 at SIO, in November 2003 $\left(\mathrm{C}_{3} \mathrm{~F}_{8}\right)$ and January $2004\left(\mathrm{C}_{2} \mathrm{~F}_{6}\right)$ at the remote AGAGE stations Mace Head (MHD, $53^{\circ} \mathrm{N}, 10^{\circ} \mathrm{W}$, Ireland), in January $\left(\mathrm{C}_{3} \mathrm{~F}_{8}\right)$ and April $2004\left(\mathrm{C}_{2} \mathrm{~F}_{6}\right)$ at Cape Grim (CGO, 41 ${ }^{\circ} \mathrm{S}$, $145^{\circ} \mathrm{E}$, Australia), in April 2005 at Trinidad Head (THD, $41^{\circ} \mathrm{N}, 124^{\circ} \mathrm{W}$, California), in May 2005 at Ragged Point $\left(\mathrm{RPB}, 13^{\circ} \mathrm{N}, 59^{\circ} \mathrm{W}\right.$, Barbados), and in May 2006 at Cape Matatula (SMO, $14^{\circ} \mathrm{S}, 171^{\circ} \mathrm{W}$, American Samoa). Due to initial experimental difficulties from carbon dioxide interference, $\mathrm{CF}_{4}$ data are used starting in April (THD), May (CGO, MHD), and June 2006 (RPB, SMO). Each sample was alternated with a reference gas analysis (Prinn et al., 2000; Miller et al., 2008), resulting in up to 12 fully calibrated samples per day. The reference gases at each site were calibrated relative to parent standards at SIO. Details of the calibration chain are reported in Miller et al. (2008).

$\mathrm{CF}_{4}$ is reported on the SIO-2005 scale, $\mathrm{C}_{2} \mathrm{~F}_{6}$ and $\mathrm{C}_{3} \mathrm{~F}_{8}$ on the SIO-2007 scale, as parts per trillion (ppt) dry air mole fractions. All are based on volumetric halocarbon/nitrous oxide $\left(\mathrm{N}_{2} \mathrm{O}\right)$ mixtures via a stepwise dilution technique with large dilution factors for each step $\left(10^{3}\right.$ to $\left.10^{5}\right)$ (Prinn et al., 2000, 2001). The SIO-2005 $\mathrm{CF}_{4}$ scale is based on four mixtures in artificial air with prepared values of 83.77-84.74 ppt. The SIO-2007 $\mathrm{C}_{2} \mathrm{~F}_{6}$ and $\mathrm{C}_{3} \mathrm{~F}_{8}$ scales are based on 4 and 5 mixtures with prepared values of $4.19-4.21 \mathrm{ppt}_{2} \mathrm{~F}_{6}$ and 2.27-2.61 ppt $\mathrm{C}_{3} \mathrm{~F}_{8}$, respectively, each containing $\sim 20$ torr water vapor. The pure $\mathrm{CF}_{4}$ (99.997\%, Aldrich), $\mathrm{C}_{2} \mathrm{~F}_{6}$ (99.99\%, SynQuest Laboratories), $\mathrm{C}_{3} \mathrm{~F}_{8}$ (>=99.9\%, SynQuest Laboratories), and $\mathrm{N}_{2} \mathrm{O}$ (99.99\%, Matheson) were further purified by repeated cycles of freezing $\left(-196^{\circ} \mathrm{C}\right)$, vacuum removal of non-condensable gases, and thawing. Artificial air (Ultra Zero Grade, Airgas) was further purified via an absorbent trap filled with glass beads, Molecular Sieve (MS) $13 \mathrm{X}$, charcoal, MS $5 \AA$, and Carboxen 1000 at $-80^{\circ} \mathrm{C}$ (ethanol/dry ice). Each zero air sample was measured to verify insignificant halocarbon blank levels before being spiked with the halocarbon $/ \mathrm{N}_{2} \mathrm{O}$ mixtures.

Due to the high volatility of $\mathrm{CF}_{4}$ and the residual vapor pressure of 0.04 mbar at liquid nitrogen $\left(\mathrm{N}_{2}(1)\right)$ temperature (Lide, 1993, 2003) the transfer order of $\mathrm{N}_{2} \mathrm{O}$ and halocarbon to the stainless steel mixture canister had to be reversed for $\mathrm{CF}_{4}$ compared to the method described in Prinn et al. (2000) to minimize the volume into which $\mathrm{CF}_{4}$ expands and to minimize the size of the correction needed for the residual $\mathrm{CF}_{4}$ vapor. The accurately measured bootstrap $\mathrm{N}_{2} \mathrm{O}$ was first vacuum-transferred to the mixture canister by immersing it into $\mathrm{N}_{2}(\mathrm{l})$. Thereafter, the mixture canister and the attached capillary breaker were separated from the vacuum line and the calibrated volume (initially containing the measured $\mathrm{N}_{2} \mathrm{O}$ ). Then $\mathrm{CF}_{4}$ was released from the capillary breaker, so that it equilibrated only with the capillary breaker $(\sim 13.48 \mathrm{ml} \pm 0.02 \%)$ and the $\mathrm{N}_{2} \mathrm{O}$ filled mixture canister $(\sim 850 \mathrm{ml})$, but not with the large volume of the vacuum line. This way the only correction was for the small residual $\mathrm{CF}_{4}$ vapor in the capillary breaker $(\sim 0.02 \%)$. Systematic uncertainties are conservatively estimated at $\sim 1-2 \%$, see also Prinn et al. (2000). The SIO-2005 scale agrees with a $\mathrm{CF}_{4}$ calibration by the National Institute for Environmental Studies (NIES) in Japan (Y. Yokouchi, personal communication, 2005 ) within $1.3 \%$ and with a dilution at SIO of a commercial gravimetric $\mathrm{CF}_{4} / \mathrm{CFC}$ mixture (Linde, UK) within $0.08 \%$.

$\mathrm{CF}_{4}$ is monitored on its base (most abundant) ion, with a mass over charge ratio $(\mathrm{m} / \mathrm{z})$ of 69 , and $\mathrm{m} / \mathrm{z} 50$ is used as a qualifier ion. $\mathrm{C}_{2} \mathrm{~F}_{6}$ is monitored on $\mathrm{m} / z 119$ for which interference is much less likely than for its base $m / z 69$ which is used as a qualifier. Similarly $\mathrm{C}_{3} \mathrm{~F}_{8}$ is monitored on $\mathrm{m} / 2$ 169 due to interference on its base $m / z 69$. Typical daily precisions of reference gas measurements are $0.05-0.2 \mathrm{ppt}$ (0.06-0.3\%) for $\mathrm{CF}_{4}, 0.02-0.06 \mathrm{ppt}(0.5-1.5 \%)$ for $\mathrm{C}_{2} \mathrm{~F}_{6}$, and $0.007-0.02 \mathrm{ppt}(1.5-4.5 \%)$ for $\mathrm{C}_{3} \mathrm{~F}_{8}$ at all sites. Typical precisions for archived air samples (see next section) were $\sim 0.08 \mathrm{ppt}$ for $\mathrm{CF}_{4}, \sim 0.03$ ppt for $\mathrm{C}_{2} \mathrm{~F}_{6}, \sim 0.01 \mathrm{ppt}$ for $\mathrm{C}_{3} \mathrm{~F}_{8}$, with 3-4 replicates for most older and 10-12 for most newer samples. Replicate analyses of $\mathrm{NH}$ archived air samples (see next section) over 2.5-4 years typically agree with precisions of less than $0.1 \mathrm{ppt}$ for $\mathrm{CF}_{4}, 0.04 \mathrm{ppt}$ for $\mathrm{C}_{2} \mathrm{~F}_{6}$, and $0.01 \mathrm{ppt}$ for $\mathrm{C}_{3} \mathrm{~F}_{8}$, showing that the PFCs are stable. Replicate analyses of $\mathrm{SH}$ archived air samples during the measurements of the Cape Grim Air Archive (CGAA, see next section) at CSIRO typically agree with precisions of less than $0.1 \mathrm{ppt}$ for $\mathrm{CF}_{4}, 0.02$ ppt for $\mathrm{C}_{2} \mathrm{~F}_{6}$, and $0.006 \mathrm{ppt}$ for $\mathrm{C}_{3} \mathrm{~F}_{8}$. Detection 


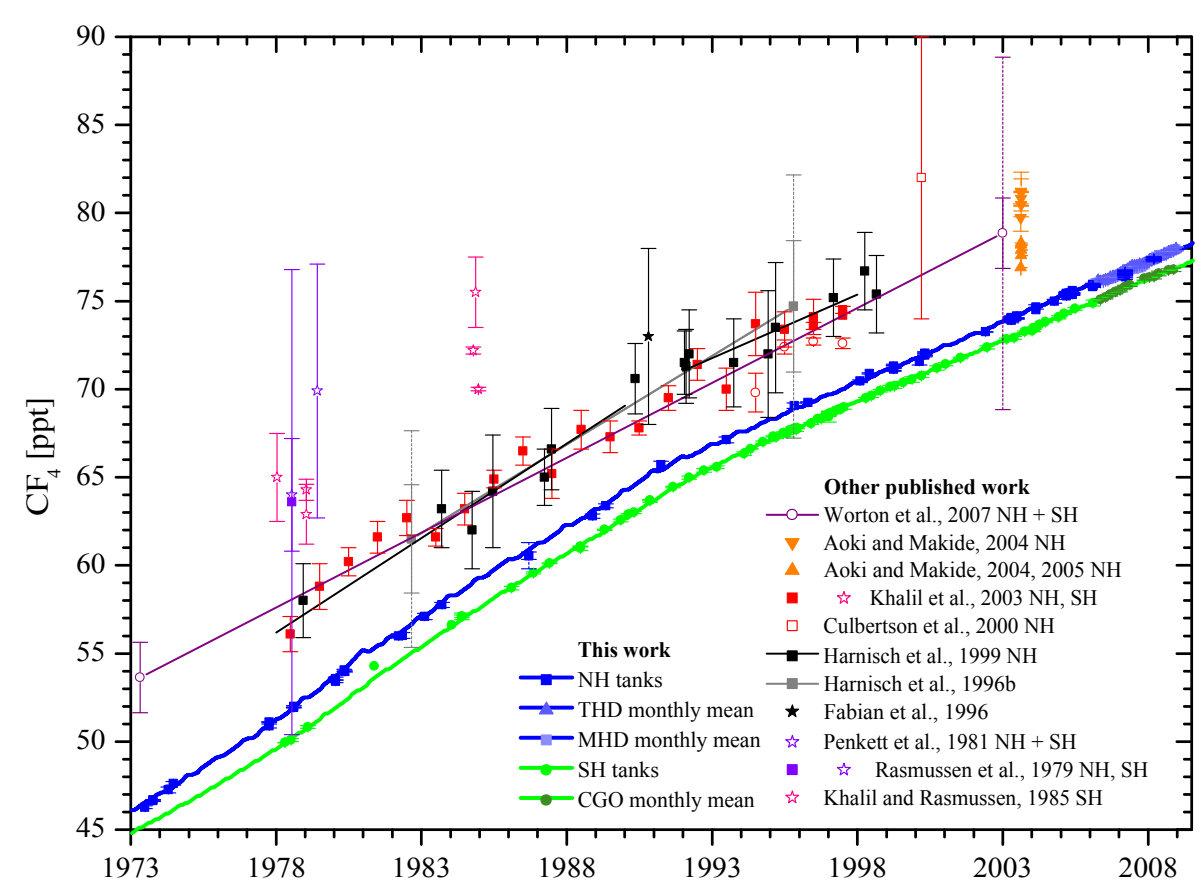

Fig. 1. AGAGE $\mathrm{CF}_{4}$ abundances from archived Northern Hemisphere (NH) and Southern Hemisphere (SH) air samples and in situ measurements at Mace Head, Ireland (NH), Trinidad Head, California (NH), and Cape Grim, Tasmania (SH) and modeled 30-90 $\mathrm{N}$ and 30-90 $\mathrm{S}$ abundances all shown on the SIO-2005 calibration scale compared to previous observations. Uncertainty estimates for the SIO-2005, MPAE 86, and UEA calibration scales are indicated as additional dashed error bars.

limits ( 3 times baseline noise) for $2 \mathrm{~L}$ ambient air samples were $\sim 0.2 \mathrm{ppt}$ for $\mathrm{CF}_{4}, \sim 0.02 \mathrm{ppt}$ for $\mathrm{C}_{2} \mathrm{~F}_{6}$, and $\sim 0.02 \mathrm{ppt}$ for $\mathrm{C}_{3} \mathrm{~F}_{8}$ at $\mathrm{SIO}$ and CSIRO.

The analytical systems showed no $\mathrm{CF}_{4}$ blanks. At SIO, small $\mathrm{C}_{2} \mathrm{~F}_{6}$ and $\mathrm{C}_{3} \mathrm{~F}_{8}$ blanks were observed due to impurity of the helium carrier gas. This carrier gas blank was carefully assessed for each helium tank. If the blank variability was negligible, all measurements made using a particular carrier gas tank were blank corrected to remove non-linearity effects, otherwise measurements with variable and high blank were rejected. The resulting uncertainties due to the blank level variability are negligible compared to the overall precisions for $\mathrm{C}_{2} \mathrm{~F}_{6}$ and $\mathrm{C}_{3} \mathrm{~F}_{8}$. The linearity of the Medusa GC/MSD system used for the measurements of archived air from the SH (CGAA, see next section) was assessed with a series of diluted air samples (3.7-57 $\mathrm{ppt} \mathrm{CF}_{4}, 0.3-$ 3.4 ppt $\mathrm{C}_{2} \mathrm{~F}_{6}$, and $0.02-0.34$ ppt $\mathrm{C}_{3} \mathrm{~F}_{8}$ ). For $\mathrm{CF}_{4}$ and $\mathrm{C}_{2} \mathrm{~F}_{6}$ no corrections were necessary, but for $\mathrm{C}_{3} \mathrm{~F}_{8}$ a non-linearity correction of $\sim 6 \%(0.003 \mathrm{ppt})$ had to be applied for the oldest samples - however this correction is so small for these low abundances that the corrected and uncorrected results for most samples still agree within measurement precisions.

\subsection{Archived air samples of the Northern and Southern Hemisphere}

To reconstruct the atmospheric history of $\mathrm{CF}_{4}, \mathrm{C}_{2} \mathrm{~F}_{6}$, and $\mathrm{C}_{3} \mathrm{~F}_{8}, 124$ unique archived Northern Hemisphere $(\mathrm{NH}$, 1973-2008) air samples were measured at SIO, and 64 unique archived Southern Hemisphere (SH, 1978-2006) air samples from the Cape Grim Air Archive (CGAA) (Krummel et al., 2007) were measured at CSIRO. Six additional SH samples with fill dates ranging from 1995 to 2004 were measured at SIO. For $\mathrm{CF}_{4}$ and $\mathrm{C}_{2} \mathrm{~F}_{6}$ all six samples were in excellent agreement with the $\mathrm{SH}$ samples with similar fill dates measured at CSIRO (delta mole fraction $\Delta x=0.01-0.16 \mathrm{ppt} \mathrm{CF}_{4}, \quad \Delta x=0.02-0.03 \mathrm{ppt}_{2} \mathrm{~F}_{6}$, $\Delta x=0.001-0.014$ ppt $\mathrm{C}_{3} \mathrm{~F}_{8}, \Delta t=3-33$ days). For $\mathrm{C}_{3} \mathrm{~F}_{8}$ one sample was rejected as an outlier with lower than expected $\mathrm{C}_{3} \mathrm{~F}_{8}$ mixing ratios $(\Delta x=0.04 \mathrm{ppt})$. Similarly, five additional $\mathrm{NH}$ samples with fill dates ranging from 1980 to 1999 were measured at CSIRO. For $\mathrm{CF}_{4}$ and $\mathrm{C}_{2} \mathrm{~F}_{6}$ three of the five samples were in excellent agreement with the $\mathrm{NH}$ samples with similar fill dates measured at $\mathrm{SIO}\left(\Delta x=0.07-0.13 \mathrm{ppt} \mathrm{CF}_{4}\right.$, $\Delta x=0-0.01$ ppt $_{2} \mathrm{~F}_{6}, \Delta t=0-9$ days). For $\mathrm{C}_{3} \mathrm{~F}_{8}$ four of the five samples were in excellent agreement $(\Delta x=0-0.011 \mathrm{ppt}$ $\mathrm{C}_{3} \mathrm{~F}_{8}$ ). For one of the $\mathrm{NH}$ samples measured at CSIRO the corresponding $\mathrm{NH}$ sample with similar fill date measured at SIO was rejected as an outlier with lower than expected $\mathrm{CF}_{4}$ and $\mathrm{C}_{2} \mathrm{~F}_{6}$ mixing ratios $\left(\Delta x=1.13 \mathrm{pptCF}_{4}\right.$, 
$\Delta x=0.06$ ppt $\mathrm{C}_{2} \mathrm{~F}_{6}, \Delta t=12$ days). The fifth $\mathrm{NH}$ sample measured at CSIRO had a unique fill date ( $\Delta t=81$ days to other tanks) but was rejected as a clear outlier for all PFCs. These tests show that measurements at the two sites are in agreement at least for mixing ratios ranges of $54.0-73.4 \mathrm{ppt} \mathrm{CF}_{4}$, $1.2-3.4$ ppt $\mathrm{C}_{2} \mathrm{~F}_{6}$, and $0.06-0.37$ ppt $_{3} \mathrm{~F}_{8}$. Based on greater than $2 \sigma$ deviations from a curve fit through all 70 (64 at CSIRO and 6 at SIO) SH samples, one $\mathrm{CF}_{4}$, ten $\mathrm{C}_{2} \mathrm{~F}_{6}$, and seven $\mathrm{C}_{3} \mathrm{~F}_{8}$ samples were rejected as outliers leaving $69 \mathrm{CF}_{4}$ (99\%), $60 \mathrm{C}_{2} \mathrm{~F}_{6}(86 \%)$, and $63 \mathrm{C}_{3} \mathrm{~F}_{8}$ (90\%) SH samples.

The 129 unique $\mathrm{NH}$ samples (124 at SIO and 5 at CSIRO) were provided mainly by the laboratories of R. F. Weiss, C. D. Keeling, and R. Keeling at SIO, and also by the Global Monitoring Division (GMD) at the National Oceanic and Atmospheric Administration (NOAA), the Norwegian Institute for Air Research (NILU), CSIRO, and the University of California at Berkeley (UCB). They were mostly filled during baseline conditions, but with different techniques and for different purposes. For $\mathrm{CF}_{4} 29 \mathrm{NH}$ samples were rejected as outliers with mostly higher mixing ratios for reasons such as initial retention of analytes on drying agents used during the filling followed by breakthrough, or sampling of polluted air, leaving $100 \mathrm{CF}_{4}(76 \%) \mathrm{NH}$ samples. Excellent atmospheric records from 1973-2007 for the NH and from 1978-2007 for the $\mathrm{SH}$ resulted for $\mathrm{CF}_{4}$. For the less volatile and less abundant $\mathrm{C}_{2} \mathrm{~F}_{6}$ and $\mathrm{C}_{3} \mathrm{~F}_{8}$, more outliers and more scatter were observed. For $\mathrm{C}_{2} \mathrm{~F}_{6} 55 \mathrm{NH}$ samples were rejected as outliers, leaving $74 \mathrm{C}_{2} \mathrm{~F}_{6}(57 \%) \mathrm{NH}$ samples. For $\mathrm{C}_{3} \mathrm{~F}_{8} 56 \mathrm{NH}$ samples were rejected as outliers, leaving $73 \mathrm{C}_{3} \mathrm{~F}_{8}(57 \%) \mathrm{NH}$ samples. Nevertheless, consistent atmospheric records were reconstructed for $\mathrm{C}_{2} \mathrm{~F}_{6}$ and $\mathrm{C}_{3} \mathrm{~F}_{8}$.

\subsection{Ancient air extracted from glacial ice and old air extracted from firn}

To assess the pre-industrial, natural background abundances of $\mathrm{CF}_{4}, \mathrm{C}_{2} \mathrm{~F}_{6}$, and $\mathrm{C}_{3} \mathrm{~F}_{8}$, we measured ancient $\mathrm{NH}$ air extracted from melted glacial ice (V. V. Petrenko and J. P. Severinghaus, SIO) which were collected in 2004 and 2005 at the Pâkitsoq site (Petrenko et al., 2008, 2009), an ice margin ablation site in Western Greenland $\left(69.43^{\circ} \mathrm{N}, 50.25^{\circ} \mathrm{W}\right)$ (Reeh et al., 1991; Petrenko et al., 2006), where ice dating from the last glacial termination is exposed. Of the eleven samples two had ages of $\sim 11360 \mathrm{BP}$ (Pre-boreal), two of $\sim 11550$ BP (transition from Pre-Boreal to Younger Dryas), two of $\sim 11600 \mathrm{BP}$ (Younger Dryas), two of $\sim 14500 \mathrm{BP}$ (Bølling), two of $\sim 14800 \mathrm{BP}$ (Oldest Dryas), and one of $\sim 19000$ BP (Last Glacial Maximum) (BP, "before present", i.e. before 1 January 1950). We also measured old SH air extracted from Antarctic firn (J. P. Severinghaus, SIO) collected on 6-17 January 2004 in 6 L Silcosteel tanks (Restek Corp.) at the Megadunes site in Antarctica $\left(80.78^{\circ} \mathrm{S}, 124.5^{\circ} \mathrm{E}\right)$ (Courville et al., 2007; Severinghaus et al., 2009). The deepest firn sample $(67.44 \mathrm{~m})$ had a mean air-age of $\sim 1910$ based on a refined firn gas-diffusion forward model similar to
Schwander et al. (1993) and Severinghaus and Battle (2006) developed at SIO (Shields et al., 2007; J. E. Shields, personal communication, 2009).

\section{Modeling studies}

\subsection{Two-Dimensional 12-box model}

A 2-D 12-box chemical transport model was used to simulate time-varying monthly background semi-hemispheric abundances in eight tropospheric and four stratospheric boxes, with horizontal divisions at the poles, $\pm 30^{\circ}$ and at the equator and with vertical divisions at 1000, 500, 200 and $0 \mathrm{hPa}$. Measured abundances were compared to the four surface model boxes. The model uses zonally averaged velocities and parameterized diffusion coefficients that exhibit seasonal variation but are annually repeating. This 2-D model has been used successfully in several previous studies to simulate the zonally averaged behavior of gases with lifetimes that are long compared to the interhemispheric exchange time and that show no sharp emissions changes (Cunnold et al., 1983, 1994, 2002). The PFCs, with lifetimes of thousands of years (Table 1), clearly satisfy this requirement. The computational efficiency of the 2-D model allows for calculation of model parameter errors and the resulting uncertainties in the inversion.

\subsection{Inversion approach for $\mathrm{CF}_{4}, \mathrm{C}_{2} \mathrm{~F}_{6}$, and $\mathrm{C}_{3} \mathrm{~F}_{8}$}

Annual emissions were deduced for the four semihemispheres using an approach based on a Bayesian discrete recursive weighted least squares filter (Prinn, 2000). The unknowns were annual emissions from 1973-2009 for each of the four semi-hemispheres. "Pulses" of emissions were released sequentially for each year and in each semihemisphere and the resulting mole fractions were tracked through the model to estimate the time-varying sensitivity of the mole fractions in each box to annual emissions from each source region. Given these sensitivities, the filter was used to combine information between a prior "guess" of the emissions and information from each measurement, weighted by their uncertainties. Total uncertainties include those derived from the filter as well as an estimate of the influence of errors in the model parameters, including errors in interhemispheric and stratosphere-troposphere mixing times.

Initial estimates of PFC emissions prior to the earliest sample date (1973) of air measured by AGAGE were determined using primary Al production from 1900-1972 (US Geological Survey, 1932-2009) multiplied by constant emission factors (EF, $\mathrm{kg} \mathrm{PFC} /$ tonne $\mathrm{Al}$ produced). Emissions during this period were required to spin up the model from a globally well-mixed atmosphere in 1900, in which pre-industrial mole fractions were assumed. EFs were derived from 1973 PFC emissions in the EDGAR v4 emission database (2009) for $\mathrm{CF}_{4}$ and $\mathrm{C}_{2} \mathrm{~F}_{6}$ and from preliminary measurements in 
an Australian $\mathrm{Al}$ smelter for $\mathrm{C}_{3} \mathrm{~F}_{8}$ and scaled throughout this model spin-up period using the 1973 emissions derived from the inversion, resulting in $1.14 \mathrm{~kg} \mathrm{CF}_{4} /$ tonne $\mathrm{Al}$, $0.117 \mathrm{~kg} \mathrm{C}_{2} \mathrm{~F}_{6} /$ tonne $\mathrm{Al}$, and $0.0055 \mathrm{~kg} \mathrm{C}_{3} \mathrm{~F}_{6} /$ tonne Al. As we have not measured any air collected prior to 1973 , the temporal evolution of the emission factors before 1973 could not be determined. We assumed a $30 \%$ uncertainty for the 1973 EDGAR v4 (2009) emissions and set an initial semihemispheric distribution using 1970 EDGAR 32/FT2000 gridded data (Olivier and Berdowski, 2001) due to lack of 1970 EDGAR v4 gridded data.

EDGAR v4 and other previous estimates are substantially different from emissions derived from AGAGE measurements and their use as independent "prior" emissions in the inversion led to unduly biased inversion results. Therefore, the approach was modified so that after 1973, "prior" emissions for each year were assumed to be the emissions from the previous year with a $1 \sigma$ uncertainty of $5 \%$ for $\mathrm{CF}_{4}$ and $\mathrm{C}_{2} \mathrm{~F}_{6}$ and $20 \%$ for $\mathrm{C}_{3} \mathrm{~F}_{8}$. These constraints on emission changes were included in the inversion to avoid unrealistically large emission changes. They were consistent with the expected rate of change of emissions, based on the maximum rate of change of the mixing ratio growth during each time series. To account for the low frequency of archive data, this was achieved by fitting a sixth order polynomial and finding the maximum of the second derivative and normalizing to the growth rate to find the fractional change in emissions.

The structure of the emissions vector, $\boldsymbol{x}$ and error covariance matrix, $\mathbf{P}$ are shown in Eqs. (1-2). $\boldsymbol{x}$ contains subvectors of emissions $q_{i}$ for year $i$, with each $q_{i}$ containing emissions from the four semi-hemispheres. Similarly, each element in $\mathbf{P}$ is a sub-matrix with errors from the four semihemispheres. The diagonal elements, $\sigma_{i i}^{2}$ of the error covariance matrix, contain the square of emissions errors in year $i$, while the off-diagonal terms correspond to errors from spatial and temporal correlations. Initially all annual emissions were assumed to be uncorrelated.

An estimate of the emissions time series was made by sequentially incorporating measurements at time-step $k$ and updating the emissions vector and error covariance matrix as shown by Eqs. (3-5). Superscripts $f$ and $a$ refer to forecasted and analyzed values, $\mathbf{H}_{k}$ is a Jacobian matrix describing the sensitivity of mole fractions to changes in emissions, $\boldsymbol{y}_{k}^{0}$ and $\boldsymbol{y}_{k}$ refer to observed and simulated mole fractions, respectively, and $\mathbf{R}_{k}$ is the measurement covariance matrix, with diagonal elements equal to the square of the measurement error.

$\boldsymbol{x}_{k}^{f}=\left[q_{1}, q_{2} \ldots q_{37}\right]^{T}$

$\mathbf{P}_{k}^{f}=\left[\begin{array}{cccc}\sigma_{1,1}^{2} & 0 & \ldots & 0 \\ 0 & \sigma_{2,2}^{2} & \ldots & 0 \\ \vdots & \vdots & \ddots & \vdots \\ 0 & 0 & \ldots & \sigma_{37,37}^{2}\end{array}\right]$
$\boldsymbol{x}_{k}^{a}=\mathbf{K}_{k}\left(\boldsymbol{y}_{k}^{o}-\boldsymbol{y}_{k}\right)+\boldsymbol{x}_{k}^{f}$

$\mathbf{P}_{k}^{a}=\left(\mathbf{I}-\mathbf{K}_{k} \mathbf{H}_{k}\right) \mathbf{P}_{k}^{f}$

$\mathbf{K}_{k}=\mathbf{P}_{k}^{f} \mathbf{H}_{k}^{T}\left(\mathbf{H}_{k} \mathbf{P}_{k}^{f} \mathbf{H}_{k}^{T}+\mathbf{R}_{k}\right)^{-1}$

To begin, the first measurement (at $k=0$ ) was incorporated, leading to an update of the emissions vector and covariance matrix. Only the first element was updated, since there is no sensitivity to future emissions. Next, emissions were forecasted for the second year to be the same as the current emission estimate from the first year (first year emissions could still be updated as more measurements were incorporated), \pm the expected maximum growth rate. The entire emissions vector was then updated through Eqs. (3-5) by incorporating the second measurement, leading to a new estimate of the emissions vector and error covariance matrix. This process was used for the thirty-seven year period in the inversion. Monthly measurements were used, when available, to update annual emissions which were assumed to be constant over the year.

Measurement uncertainties were calculated as the square root of the sum of the squared errors resulting from sampling frequency, measurement-model mismatch, instrumental precision, and scale propagation. Sampling frequency error characterizes the uncertainty that arises from using a finite number of measurements to define a time-varying monthly mean mixing ratio and was estimated as the square root of the ratio of the monthly mean baseline variability to the number of measurements. Since the monthly mean variance was only known at high-frequency stations, it was defined for flask measurements as having the same variance as at the high-frequency stations in the same semi-hemisphere, scaled by the mean mole fraction. Mismatch error is associated with how well the point measurements represent the background, semi-hemispheric mole fractions assumed in the model. It was estimated here as equal to the scaled variability of the high-frequency station in the same latitude band as the archived air measurements, and reflects the inability of the model to account for spatial gradients within each semihemisphere. Precisions are specific to each gas, as is discussed below, and are inversely scaled with the square root of the number of measurements. Scale propagation error is associated with calibration tank changes and calibration scale propagation. It was estimated as equal to the precision error but independent on the number of measurements.

\section{Results and discussion}

\subsection{Atmospheric records spanning more than 30 years in each hemisphere}

The atmospheric histories of $\mathrm{CF}_{4}, \mathrm{C}_{2} \mathrm{~F}_{6}$, and $\mathrm{C}_{3} \mathrm{~F}_{8}$ in the $\mathrm{SH}$ shown in green colors in Figs. 1, 2, and 3 were reconstructed from analysis of archived $\mathrm{SH}$ air from the Cape 
Grim Air Archive (CGAA) (Krummel et al., 2007) and background monthly mean in situ data for Cape Grim, Tasmania. The atmospheric histories in the NH shown in blue colors in Figs. 1, 2, and 3 were reconstructed from analysis of archived $\mathrm{NH}$ air (mostly from Trinidad Head and La Jolla, California [SIO samples] and also from Point Barrow, Alaska [UCB samples], Niwot Ridge, Colorado [NOAA/GMD and CSIRO samples], Cape Meares, Oregon [NOAA/GMD, NILU, and CSIRO samples, originally collected by R. A. Rasmussen, Oregon Graduate Institute (OGI)], and Harvard Forest, Massachusetts [SIO samples]) and background monthly mean in situ data for Trinidad Head, California and Mace Head, Ireland. The combined data yield records spanning more than 30 years for each PFC in both hemispheres. Archived air and in situ data agree very well during the overlap periods for all three PFCs in the NH and for $\mathrm{C}_{2} \mathrm{~F}_{6}$ in the $\mathrm{SH}$. For $\mathrm{C}_{3} \mathrm{~F}_{8}$ some $\mathrm{SH}$ archive samples are slightly elevated but in 2005 and 2006 the agreement is excellent. For $\mathrm{CF}_{4}$ there is no overlap period, but a continuous transition occurred without any apparent steps. The start times of in situ measurements for each compound at each site are provided in Sect. 2.1. For details on archived air samples see Sect. 2.2. This degree of agreement, as well as the results of the tests described in Sect. 2.2 document that the Medusa GC/MSD instruments and calibration methods result in highly consistent data sets. The AGAGE PFC data sets for the NH start five years earlier and end eleven to twelve years later than previously reported data sets of direct PFC measurements in air samples (Harnisch et al., 1999; Khalil et al., 2003; Culbertson et al., 2004). The lengths of the AGAGE PFC data sets in the SH are unique.

\subsection{1 $\mathrm{CF}_{4}$ measurements}

The precision of our AGAGE $\mathrm{CF}_{4}$ data, $<0.3 \%$, or $<0.2 \mathrm{ppt}$ (Fig. 1), is substantially improved compared to previous methods (typically $\sim 5 \%$, or a few ppt, Fig. 1 and Table 3). Together with the high integrity of both the archived air samples and the in situ data, this precision leads to well-defined abundances and rise rates in both hemispheres (Fig. 1 and Table 3 ) with the first clearly defined interhemispheric gradients. $\mathrm{CF}_{4}$ rise rates were $\sim 1.07 \mathrm{ppt} / \mathrm{yr}$ until $\sim 1991$ and $\sim 0.7 \mathrm{ppt} / \mathrm{yr}$ since $\sim 1993$, similar to previous reports but better constrained (Table 3). A decrease of the $\mathrm{CF}_{4}$ rise rate is clearly evident between $\sim 1991$ and $\sim 1994$, mostly likely due to increased efficiency of the $\mathrm{Al}$ industry and resulting reduced emissions as reported by the International (Primary) Aluminium Institute (1996, 2009a).

The estimated uncertainty of AGAGE $\mathrm{CF}_{4}$ data on the SIO-2005 $\mathrm{CF}_{4}$ scale is at $\sim 1-2 \%$ (Fig. 1) less than the $\sim 10 \%$ stated uncertainty for the widely used MPAE 86 (Max Planck Institute for Aeronomy) calibration scale (Fabian et al., 1996; Harnisch et al., 1996b, 1999) and the $\sim 10 \mathrm{ppt}$, or $13.9 \%$ for the UEA (University of East Anglia) calibration scale (Worton et al., 2007) (Fig. 1, Table 3). As described in Sect. 2.1, the accuracy estimate of the SIO-2005 scale is supported by the good agreement with two independent $\mathrm{CF}_{4}$ calibration mixtures.

The $\mathrm{CF}_{4}$ abundances reported here are 6-10\% lower than those in previous reports. Background tropospheric mixing ratios increased from $\sim 49.9 \mathrm{ppt}$ in 1978 to $\sim 76.9 \mathrm{ppt}$ at the end of 2008 in the SH and from $~ 46.3 \mathrm{ppt}$ in 1973 to $\sim 78.0 \mathrm{ppt}$ at the end of 2008 in the NH. Previous data with MPAE 86 and UEA calibrations actually are consistent with our AGAGE observations when calibration uncertainties are taken into account. This also applies to data presented by Khalil et al. (2003) which were scaled to agree with the MPAE 86 calibration.

Aoki and Makide (2004) recently used an independent calibration and measurement approach and reported $80.7 \pm 0.6 \mathrm{ppt} \mathrm{CF}_{4}$ in one air sample taken in Tokyo on $9 \mathrm{Au}-$ gust 2003 (Fig. 1), which is $\sim 1.5$ ppt higher than an extrapolation of previous data with MPAE 86 and UEA calibrations. Instead of measuring $\mathrm{CF}_{4}$ directly, they measured the $\mathrm{CF}_{4} /{ }^{80} \mathrm{Kr}$ ratio to circumvent the substantial matrix and separation problems associated with the inevitable co-trapping of $\mathrm{CF}_{4}$ and major atmospheric constituents. They used ${ }^{80} \mathrm{Kr}$ as an internal standard, relying on the precise knowledge of its atmospheric abundance, its uniform distribution, and the assumption that it behaves similarly to $\mathrm{CF}_{4}$ during trapping and separation. Later Aoki and Makide (2005) revised the atmospheric ${ }^{80} \mathrm{Kr}$ abundance, which would lead to $77.8 \pm 0.6 \mathrm{ppt} \mathrm{CF}_{4}, \sim 3 \mathrm{ppt}$ lower than reported in 2004. In addition to these uncertainties, it might not be possible to measure reliable $\mathrm{CF}_{4}$ background values in a single Tokyo air sample as several significant $\mathrm{CF}_{4}$ sources are nearby according to the EDGAR 32/FT2000 emission database (Olivier and Berdowski, 2001).

\subsection{2 $\quad \mathrm{C}_{2} \mathrm{~F}_{6}$ measurements}

The precision of our AGAGE $\mathrm{C}_{2} \mathrm{~F}_{6}$ data and the quality of the archived air measurements are improved compared to most previously reported $\mathrm{C}_{2} \mathrm{~F}_{6}$ data sets, and abundances in both hemispheres are more clearly defined (Table 4, Fig. 2). It is possible to quantify consistent interhemispheric gradients for the first time, which are clearly larger than those suggested by Khalil et al. (2003) and Worton et al. (2007). Tropospheric mixing ratios increased from $\sim 0.96 \mathrm{ppt}$ in 1978 to $\sim 3.93 \mathrm{ppt}$ at the end of 2008 in the $\mathrm{SH}$ and from $\sim 0.75 \mathrm{ppt}$ in 1973 to $\sim 4.06 \mathrm{ppt}$ at the end of 2008 in the NH. The SH rise rates were $\sim 0.087 \mathrm{ppt} / \mathrm{yr}$ until $\sim 1997$ (similar to previously published $\mathrm{NH}$ rise rates), followed by a faster increase of $\sim 0.119 \mathrm{ppt} / \mathrm{yr}$ until $\sim 2004$, and a slower increase of $\sim 0.099 \mathrm{ppt} / \mathrm{yr}$ thereafter. The $\mathrm{NH} \mathrm{C}_{2} \mathrm{~F}_{6}$ data show similar trends, but it is difficult to calculate actual rise rates due to larger scatter. Trend changes may have been caused by a combination of changing emissions from the $\mathrm{Al}$ industry, a sharp increase of emissions after the introduction of $\mathrm{C}_{2} \mathrm{~F}_{6}$ as a fluorine source in semiconductor/electronics manufacture 


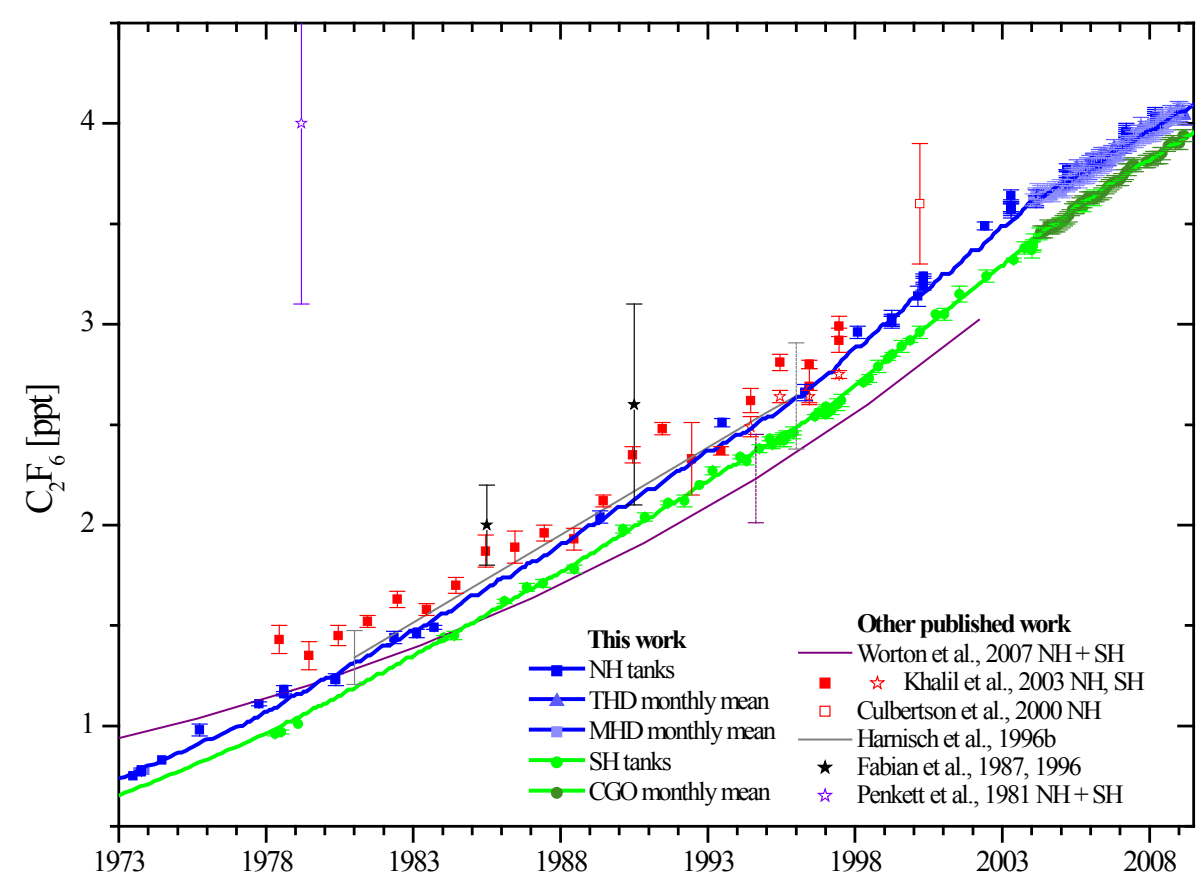

Fig. 2. AGAGE $\mathrm{C}_{2} \mathrm{~F}_{6}$ abundances from archived Northern Hemisphere (NH) and Southern Hemisphere (SH) air samples and in situ measurements at Mace Head, Ireland (NH), Trinidad Head, California (NH) and Cape Grim, Tasmania (SH) and modeled 30-90 $\mathrm{N}$ and 30-90 $\mathrm{S}$ abundances all shown on the SIO-2007 calibration scale compared to previous observations. Uncertainty estimates for the MPAE 86 and UEA scales are indicated as additional dashed error bars. For the SIO-2007 scale they are is similar to the shown measurement precisions $(\sim 1-2 \%)$.

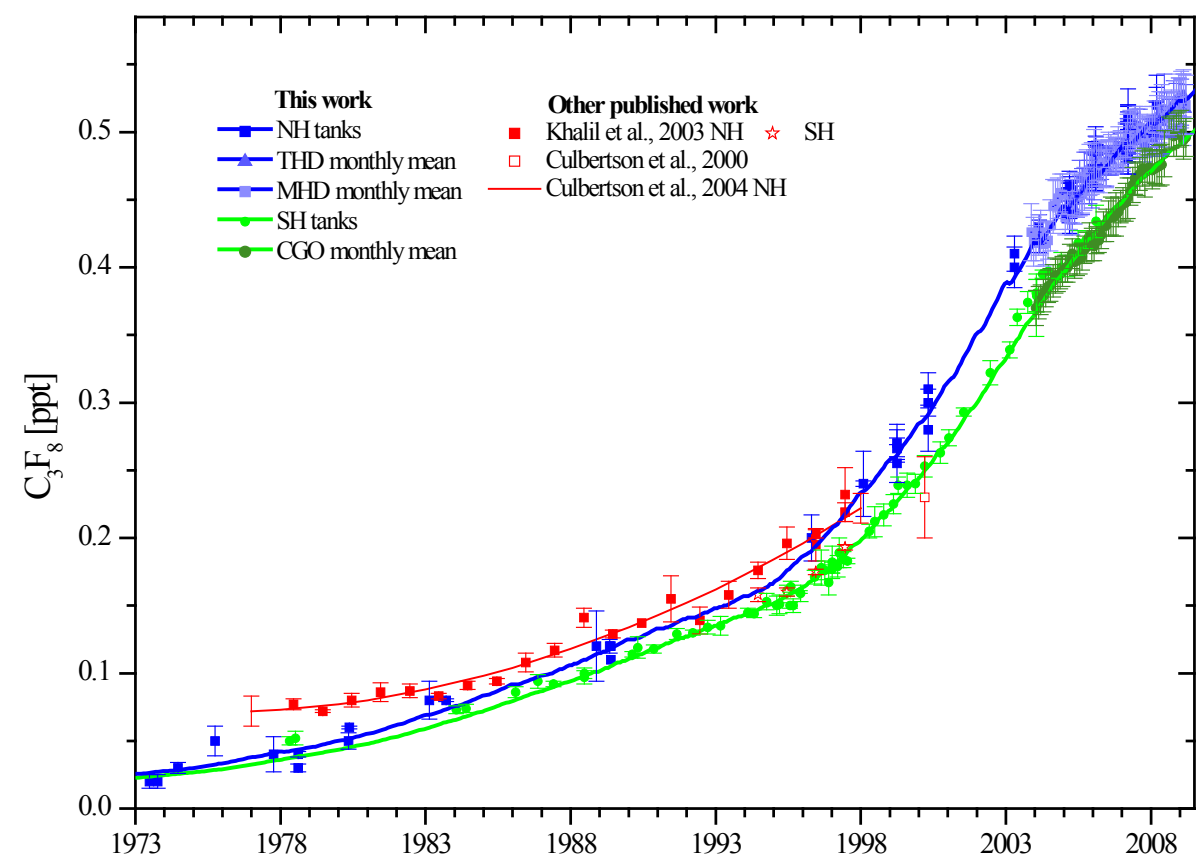

Fig. 3. AGAGE $\mathrm{C}_{3} \mathrm{~F}_{8}$ abundances from archived Northern Hemisphere (NH) and Southern Hemisphere (SH) air samples and in situ measurements at Mace Head, Ireland (NH), Trinidad Head, California (NH), and Cape Grim, Tasmania ( $\mathrm{SH}$ ) and modeled 30-90 $\mathrm{N}$ and 30-90 $\mathrm{S}$ abundances all shown on the SIO-2007 scale compared to previous observations. The SIO-2007 calibration scale uncertainty estimate $(\sim 1-2 \%)$ is similar to the shown precisions. 
in the early 1990s as indicated by the EDGAR v4 emission database (2009), followed by a gradual replacement of $\mathrm{C}_{2} \mathrm{~F}_{6}$ with more efficient fluorine sources such as nitrogen trifluoride $\left(\mathrm{NF}_{3}\right.$, Air Products, personal communications, 2009) (Weiss et al., 2008) and possibly improved abatement of $\mathrm{C}_{2} \mathrm{~F}_{6}$ emissions. $\mathrm{C}_{2} \mathrm{~F}_{6}$ mixing ratios and rise rates in the $\mathrm{NH}$ reported by Khalil et al. (2003) and Harnisch et al. (1996b) mostly agree with our AGAGE data, but $\mathrm{C}_{2} \mathrm{~F}_{6}$ mixing ratios reconstructed from firn air by Worton et al. (2007) differ significantly and show different trends.

\subsection{3 $\quad \mathrm{C}_{3} \mathrm{~F}_{8}$ measurements}

The precision of our AGAGE $\mathrm{C}_{3} \mathrm{~F}_{8}$ data is similar to the $\mathrm{C}_{3} \mathrm{~F}_{8}$ precisions of Khalil et al. (2003) and Culbertson et al. (2004), but our NH abundances are lower (Fig. 3, Table 5), especially before $\sim 1983$, and the rise rates are different. Tropospheric mixing ratios increased from $\sim 0.05 \mathrm{ppt}$ in 1978 to $\sim 0.5 \mathrm{ppt}$ at the end of 2008 in the SH and from $\sim 0.02 \mathrm{ppt}$ in 1973 to $\sim 0.52 \mathrm{ppt}$ at the end of 2008 in the $\mathrm{NH}$. Rise rates are more difficult to define than for $\mathrm{CF}_{4}$ and $\mathrm{C}_{2} \mathrm{~F}_{6}$, especially in the $\mathrm{NH}$. They were $\sim 0.0062-0.0066 \mathrm{ppt} / \mathrm{yr}$ in both hemispheres from the mid-1970s to the early-/mid-1990s, followed by a steep increase to $\sim 0.024 \mathrm{ppt} / \mathrm{yr}$ until $\sim 2000 / 2001$, and a possible further increase to $\sim 0.033 \mathrm{ppt} / \mathrm{yr}$ in the SH (20012004). Rise rates returned to $\sim 0.024 \mathrm{ppt} / \mathrm{yr}$ shortly thereafter (SH: 2004-2008, NH: 2003-2007), and declined to $\sim 0.015 \mathrm{ppt} / \mathrm{yr}$ in the NH recently (2007-2008). Without detailed information about industrial production and resulting emissions of $\mathrm{C}_{3} \mathrm{~F}_{8}$ one can only speculate that early emissions were from Al production (Harnisch et al., 1998) and that the recent large increase in emissions is due to semiconductor/electronics manufacture and refrigeration/air conditioning use (see Sect. 5.4).

\subsection{Pre-industrial abundances of $\mathrm{CF}_{4}, \mathrm{C}_{2} \mathrm{~F}_{6}$, and $\mathrm{C}_{3} \mathrm{~F}_{8}$}

We measured $34.66 \pm 0.16 \mathrm{pptCF}_{4}$ in the ancient Greenland air samples and $34.90 \pm 0.04 \mathrm{ppt}$ in the oldest $(\sim 1910)$ Antarctic firn air samples. There is only a very small difference between these two results, leading to a significantly better defined pre-industrial $\mathrm{CF}_{4}$ abundance with an overall average of $34.7 \pm 0.2 \mathrm{ppt}$ (Table 2). As expected from the calibration differences for modern data, most previously reported pre-industrial estimates were higher. However, Worton et al. (2007) present a similar pre-industrial $\mathrm{CF}_{4}$ abundance of $34 \pm 1 \mathrm{ppt}$, derived from an extrapolation of $\mathrm{CF}_{4}$ and $\mathrm{C}_{2} \mathrm{~F}_{6}$ firn data dated with a firn model to zero $\mathrm{C}_{2} \mathrm{~F}_{6}$ abundance assuming no natural $\mathrm{C}_{2} \mathrm{~F}_{6}$. This agreement is difficult to interpret, because the $\mathrm{C}_{2} \mathrm{~F}_{6}$ mixing ratios at the beginning of the Worton et al. (2007) record are higher compared to AGAGE, the curvatures of the $\mathrm{C}_{2} \mathrm{~F}_{6}$ abundances differ, and the $\mathrm{CF}_{4}$ calibration scales differ significantly (Figs. 2 and 3).

We measured $0.1 \pm 0.02 \mathrm{ppt}_{2} \mathrm{~F}_{6}$ in the lowest Megadunes firn sample. It is conceivable that this pre-industrial, back- ground $\mathrm{C}_{2} \mathrm{~F}_{6}$ level represents evidence for a small lithospheric source, as found for $\mathrm{CF}_{4}$ by Deeds et al. (2008). $\mathrm{C}_{3} \mathrm{~F}_{8}$ was below our detection limit.

\section{Global emission estimates from air archive and in situ measurements}

The global top-down emissions derived with the AGAGE 2D 12-box model (Sects. 3.1 and 3.2) are shown in Figs. 4, 5, and 6 , for $\mathrm{CF}_{4}, \mathrm{C}_{2} \mathrm{~F}_{6}$, and $\mathrm{C}_{3} \mathrm{~F}_{8}$, respectively, together with other published top-down and bottom-up emission estimates. The inversions are based on our archive and in situ real-time measurements from five remote AGAGE stations and the measured pre-industrial, natural backgrounds for $\mathrm{CF}_{4}$ and $\mathrm{C}_{2} \mathrm{~F}_{6}$ discussed above. Significant error reductions of the emissions were achieved during the inversion in all model boxes when in situ high-frequency data were available (2006-2009) and in the $30-90^{\circ} \mathrm{N}$ box for all years. From 2006-2009 the semi-hemispheric emissions for all PFCs were clearly uncorrelated $\left(R^{2}<0.1\right)$. However, before 2006 insufficient information was available to reduce the error significantly for semi-hemispheric scale emissions. Compared to the global estimates, semi-hemispheric emissions may be more sensitive to model transport parameter uncertainties and inter-annual transport variations, but the influence of these limitations are accounted for in the uncertainties of the derived emissions by including model parameters uncertainties in the error analysis. Global emissions are plotted as 5-year moving averages until 1985, 3-year moving averages from 1986 to 1999 , followed by yearly values, to avoid physically unreasonable emission changes due to the variable data density. Residuals of modeled minus observed mixing ratios are generally smaller than the measurement uncertainty (shown in Fig. S3) indicating that the derived emissions are consistent with the atmospheric measurements. Residuals that lie outside of the measurement uncertainty may have occurred when the sampled air was not truly representative of the semi-hemispheric background.

\section{1 $\mathrm{CF}_{4}$ emissions}

AGAGE global top-down $\mathrm{CF}_{4}$ emissions (Fig. 4) were $\sim 15 \mathrm{Gg} / \mathrm{yr}$ in 1975 , rising to $\sim 18 \mathrm{Gg} / \mathrm{yr}$ around 1980 , generally declining to $\sim 11 \mathrm{Gg} / \mathrm{yr}$ in 2000 , and stabilizing at $\sim 11 \mathrm{Gg} / \mathrm{yr}$ thereafter. While Harnisch et al. $(1995,1996 \mathrm{~b}$, 1999) report similar top-down averaged emissions before 1996, Khalil et al. (2003) estimate slightly lower average topdown emissions, and Worton et al. (2007) report substantially lower emissions before the mid-1990s (Table 6).

Similarly, $\mathrm{CF}_{4}$ emissions reported before $\sim 1991$ by EDGAR v4 (2009) are significantly lower while their agreement with AGAGE top-down emissions is good from 1991 to $\sim 2005$ (and until 2008 if extrapolated). It is important to note that EDGAR v4 does not simply use 2006 
Intergovernmental Panel on Climate Change (IPCC) Guidelines to estimate $\mathrm{CF}_{4}$ emissions from $\mathrm{Al}$ production, but that EDGAR v4 $\mathrm{CF}_{4}$ emission factors, including their trend after 1985, have been selected to be compatible with bottomup reporting to the UNFCCC and with previously published measured atmospheric trends (see http://edgar.jrc.ec.europa. eu/faq7.php\#flu). In other words, EDGAR v4 $\mathrm{CF}_{4}$ emissions are not pure bottom-up estimates, but rather a hybrid between bottom-up estimates and top-down interpretation of atmospheric measurements. It is unclear which atmospheric trends were used, but it seems likely that this explains the good agreement of EDGAR v4 with our AGAGE topdown emissions after $\sim 1990$, and the improved agreement before 1991 compared to EDGAR 32/FT2000 (Olivier and Berdowski, 2001) (Table 6).

The 2006-2009 emissions distribution modeled from our AGAGE measurements is $92 \pm 2 \%, 6 \pm 2 \%, 1 \pm 0.4 \%$, and $1 \pm 0.4 \%$ for the $30-90^{\circ} \mathrm{N}, 0-30^{\circ} \mathrm{N}, 0-30^{\circ} \mathrm{S}$, and $30-90^{\circ} \mathrm{S}$ semi-hemispheres, respectively. EDGAR v4 estimates $80 \%$, $11 \%, 8 \%$, and $1 \%$ for the same semi-hemispheres, respectively, in 2005. If global AGAGE emissions are distributed according to EDGAR v4, the discrepancy between modeled and observed abundances are markedly higher, indicating that EDGAR v4 probably underestimates contributions from the NH.

Also shown in Fig. 4 are $\mathrm{CF}_{4}$ emission estimates based on PFC emission data collected by the UNFCCC process (bottom-up) from the 34 Annex I reporting countries (United Nations Framework Convention on Climate Change, 2009, Supplement 1 and Table S1). These emissions have declined by more than a factor of two from $1990(9.3 \mathrm{Gg})$ to 2006 $(4.4 \mathrm{Gg})$. In 2006 they were less than half of the global $\sim 11 \mathrm{Gg} / \mathrm{yr}$ AGAGE emission estimate. This is not surprising as the UNFCCC reporting Annex I countries account for a little over 50\% of global Al production. Among nonAnnex I countries that emit PFCs from Al production are China, Brazil, South Africa, India, United Arab Emirates and Bahrain, which together accounted for $40 \%$ of 2006 global Al production (US Geological Survey, 1932-2009), thus demonstrating the need for global reporting.

To validate the PFC emission reduction measures by the global aluminum industry under the auspices of the International (Primary) Aluminium Institute (IAI), IAI has estimated global Al production PFC emissions using data on smelting-technology-specific $\mathrm{Al}$ production and $\mathrm{PFC}\left(\mathrm{CF}_{4}\right.$ and $\mathrm{C}_{2} \mathrm{~F}_{6}$ ) bottom-up emission factors (EFs) and coefficients in their IAI Anode Effect surveys (1996, 2000, 2001, 2003-2008, 2009a, b). PFC measurements made at Chinese smelters in 2008 as part of the Asia Pacific Partnership for Clean Energy and Climate and seven additional measurements reported by the Aluminum Corporation of China Limited (CHALCO) found a median emission factor for smelters using PFPB (Point Feed PreBake) technology of 0.7 tonnes $\mathrm{CO}_{2}$-equivalent $\left(\mathrm{CO}_{2}\right.$-e)/tonne $\mathrm{Al}$ produced, compared to the median performance of 0.27 tonnes $\mathrm{CO}_{2}$-e/tonne $\mathrm{Al}$ from

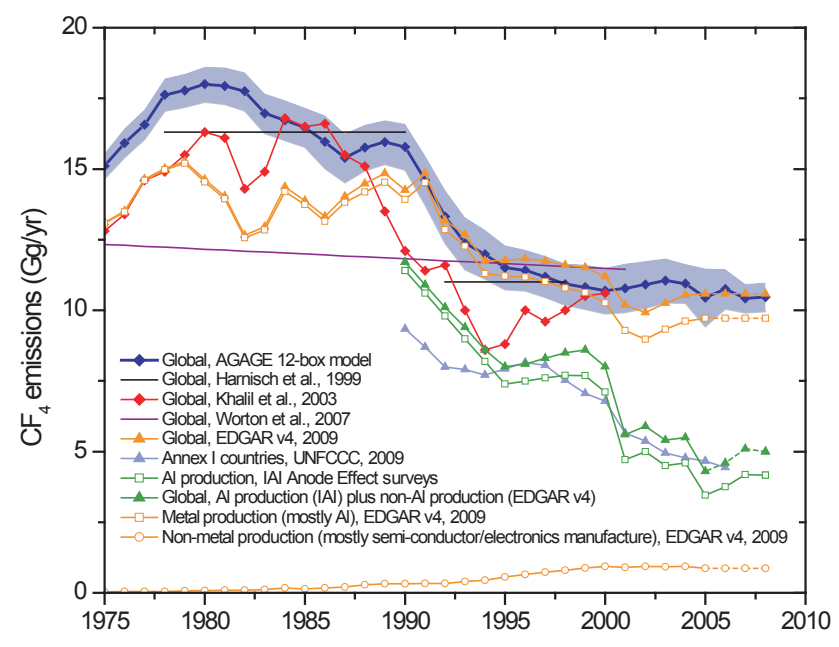

Fig. 4. Global $\mathrm{CF}_{4}$ emissions from the inversion of AGAGE atmospheric data with the AGAGE 2-D 12-box model compared to the emissions reported by Harnisch et al. (1999), Khalil et al. (2003), Worton et al. (2007), the EDGAR v4 (2009) emission database, and Annex I countries (UNFCCC, 2009, Table S1). Also shown are estimates of $\mathrm{CF}_{4}$ emissions from $\mathrm{Al}$ production (IAI Anode Effect surveys), a global $\mathrm{CF}_{4}$ emission estimate as the sum of these $\mathrm{Al}$ production $\mathrm{CF}_{4}$ emissions and non-metal production related $\mathrm{CF}_{4}$ emissions (EDGAR v4, mostly semiconductor/electronics manufacture), and the EDGAR v4 estimates for $\mathrm{CF}_{4}$ emissions from metal production (mostly Al) and non-metal production. 2005 EDGAR v4 estimates have been used for 2005-2008 (shown as dashed line).

IAI global PFPB survey participants (IAI, 2009a), or $\sim 2.6$ times higher EF. Until the mid-2000s, Chinese Al production was dominated by Horizontal Stud Soderberg (HSS) technology, but through the mid-2000s a transformation occurred in the Chinese industry and by the end of 2005 the China Non-Ferrous Metals Industry Association (CNIA) reported that all smelters used PFPB technology. Global $\mathrm{CF}_{4}$ emissions calculated from the IAI surveys increase by $\sim 0.6-$ $0.8 \mathrm{Gg} / \mathrm{yr}$ from 2006 to 2008 when the increased EF for Chinese smelters is taken into account (Supplement 2 and Table S2). The resulting corrected global Al production $\mathrm{CF}_{4}$ emissions plotted in Fig. 4 are $\sim 11.4 \mathrm{Gg} / \mathrm{yr}$ in 1990 and $\sim 3.8 \mathrm{Gg} / \mathrm{yr}$ in 2006 . When these updated IAI Al production $\mathrm{CF}_{4}$ emission estimates are added to the EDGAR $\mathrm{v} 4$ non-metal production (mostly semiconductor/electronics manufacture) $\mathrm{CF}_{4}$ emission estimates, the resulting global sum (Fig. 4) is substantially lower than AGAGE global topdown emissions, by $\sim 3.7 \pm 1.1 \mathrm{Gg} / \mathrm{yr}$ from 1990 to 1992 , by $\sim 2.5 \pm 0.5 \mathrm{Gg} / \mathrm{yr}$ from 1998 to 2000 , and by $\sim 5.9 \pm 0.3 \mathrm{Gg} / \mathrm{yr}$ from 2003 to 2005 . That is, the sum of available bottomup $\mathrm{CF}_{4}$ emission estimates is significantly lower than total global emissions as measured in the atmosphere.

One possible explanation for the growing emissions gap $(\sim 6.1 \mathrm{Gg} / \mathrm{yr}$ in 2005$)$ is that the IAI still underestimates Al production $\mathrm{CF}_{4}$ emissions from China which produced $\sim 24 \%$ of global Al in 2005 (US Geological Survey, 1932- 
Table 6. Time averaged global $\mathrm{CF}_{4}$ emission estimates.

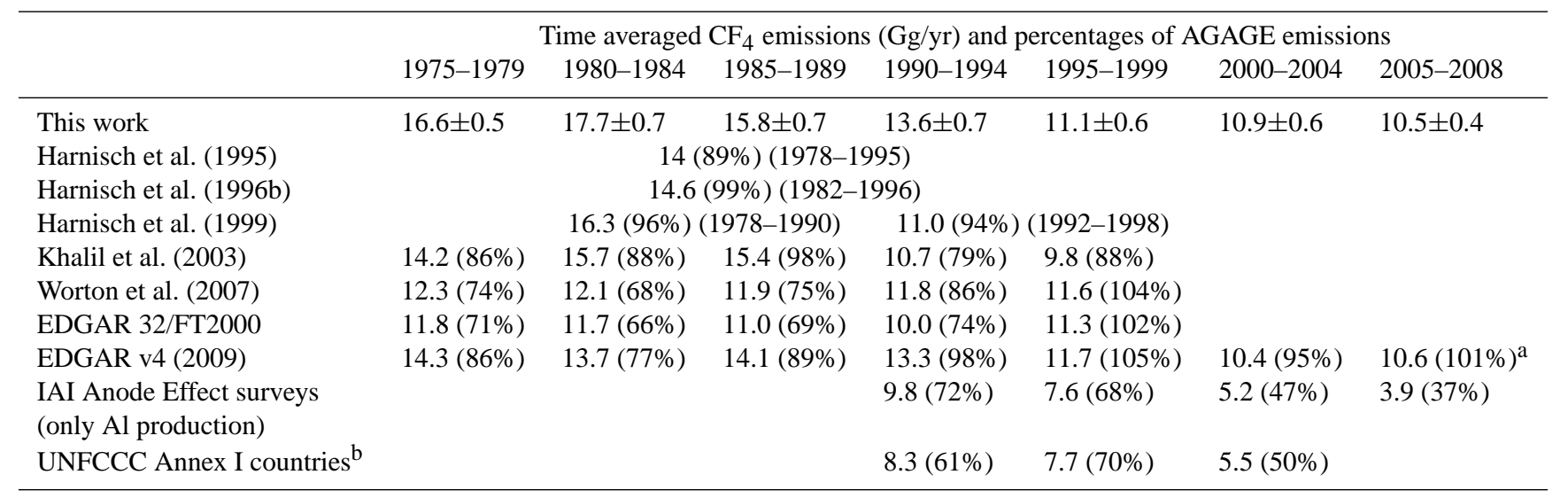

${ }^{\text {a }}$ EDGAR v4 (2009) emission estimate for 2005 used for 2005-2008.

b Based on PFC emission data collected by the UNFCCC process (United Nations Framework Convention on Climate Change, 2009).

2009) and $234 \%$ in 2008 (IAI, 2009a) - even after applying the 2.6 times larger EF for Chinese smelters using PFPB. The observed emission gap of $\sim 3.7 \pm 1.1 \mathrm{Gg} / \mathrm{yr}$ from 1990 to 1992, when China produced only $\sim 4 \%$ of global Al (IAI, 2009a), could also indicate an inherent underestimation of $\mathrm{Al}$ production $\mathrm{CF}_{4}$ emissions calculated from the surveys, as might be explained by fundamental problems with the application of IPCC methodologies. Recently Maltais et al. (2010) discovered significant PFC emissions during the startup of reduction cells which may not be accounted for by IPCC methodology. Note that EDGAR v4 metal production $\mathrm{CF}_{4}$ emissions are significantly higher than emissions estimated from the IAI surveys, but as discussed above, it remains unclear how EDGAR v4 $\mathrm{CF}_{4}$ emissions have been estimated and to what degree they depend on previous atmospheric observations. Another possible explanation for the emission gap is that PFC emissions from semiconductor/electronics manufacture in EDGAR v4, including from China, are significantly underestimated. The World Semiconductor Counsel (WSC) reports that semiconductor manufacturers in Europe, Japan, US, Korea, China, and Taiwan pursue a voluntary perfluorocompound emission reduction program and that indexed perfluorocompound emissions have increased from 1995 to 2001 by $\sim 60 \%$ and decreased slightly below 1995 values from 2001 to 2008 (http://www.sia-online.org/galleries/ Publications/2009_WSC_Joint_Statement.pdf). However, the report lists only relative emissions, does not explain how they were measured, estimated, and/or verified, and gives no information how the emissions of specific perfluorocarbons such as $\mathrm{CF}_{4}$ or $\mathrm{C}_{2} \mathrm{~F}_{6}$ have evolved. The use of the phrase perfluorocompounds instead of perfluorocarbons suggests that $\mathrm{SF}_{6}$ and $\mathrm{NF}_{3}$ may be included in the sum which would further complicate the interpretation of the WSC data. Although there are indications that continuing technology upgrades and the shutdown of older facilities for semiconductor/electronics manufacture have led to a slow replacement of $\mathrm{CF}_{4}$ with more efficient fluorine sources such as $\mathrm{NF}_{3}$ (Air Products, personal communications, 2009) which would reduce $\mathrm{CF}_{4}$ emissions from semiconductor/electronics manufacture, there are no primary sources of data to support this conclusion, and it remains unclear how $\mathrm{CF}_{4}$ or $\mathrm{C}_{2} \mathrm{~F}_{6}$ emissions from the semiconductor/electronics industry are estimated in EDGAR v4.

Lastly, we find it is surprising that UNFCCC Annex I $\mathrm{CF}_{4}$ emissions from $\mathrm{Al}$ and non-Al sources agree so well with global $\mathrm{Al}$ production related $\mathrm{CF}_{4}$ emissions estimated from the IAI reports (Annex I and non-Annex I Al production). This would require Annex I non-Al based $\mathrm{CF}_{4}$ emissions to be large and comparable to non-Annex I Al based $\mathrm{CF}_{4}$ emissions.

\section{$5.2 \quad \mathrm{C}_{2} \mathrm{~F}_{6}$ emissions}

AGAGE global top-down $\mathrm{C}_{2} \mathrm{~F}_{6}$ emissions (Fig. 5) were $\sim 1.5 \mathrm{Gg}$ in 1975 , rising to $\sim 2.2 \mathrm{Gg} / \mathrm{yr}$ during the early to mid-1990s, increasing to $\sim 3 \mathrm{Gg} / \mathrm{yr}$ during the early $2000 \mathrm{~s}$, and decreasing to $\sim 2.3 \mathrm{Gg} / \mathrm{yr}$ in 2008 . Harnisch et al. (1995, 1996b) reported similar top-down emissions until the mid1990s (2 Gg/yr, 1978-1995, 1.9 Gg/yr 1982-1996, see Table 7). Khalil et al. (2003) reported emissions similar to AGAGE until the mid-1980s (as the sum of $11.5 \%$ of $\mathrm{Al}$ production $\mathrm{CF}_{4}$ emissions and $70 \%$ of semiconductor $\mathrm{CF}_{4}$ emissions), after which they are lower by up to $\sim 0.9 \mathrm{Gg} / \mathrm{yr}$. Worton et al. (2007) estimate lower top-down $\mathrm{C}_{2} \mathrm{~F}_{6}$ emissions (Fig. 5) as expected from their lower reconstructed $\mathrm{C}_{2} \mathrm{~F}_{6}$ rise rate (Fig. 2).

While $\mathrm{C}_{2} \mathrm{~F}_{6}$ emissions in the EDGAR $\mathrm{v} 4$ emission database (2009) agree well with our AGAGE global top-down emissions before $\sim 1992$, in contrast to much 
lower emissions in the older EDGAR 32/FT2000 emission database, $\mathrm{C}_{2} \mathrm{~F}_{6}$ emissions after 1991 are lower in EDGAR $\mathrm{v} 4$ by $\sim 0.5 \mathrm{Gg} / \mathrm{yr}$. It is unclear why EDGAR $\mathrm{v}_{4} \mathrm{C}_{2} \mathrm{~F}_{6}$ emissions agree with AGAGE results before $\sim 1992$, while $\mathrm{CF}_{4}$ emissions only agree after $\sim 1990$, especially as $\mathrm{C}_{2} \mathrm{~F}_{6}$ emissions are often estimated as a constant fraction of $\mathrm{CF}_{4}$ emissions. As is the case for $\mathrm{CF}_{4}$, EDGAR v4 $\mathrm{C}_{2} \mathrm{~F}_{6}$ emission estimates are a hybrid of bottom-up methodologies and topdown estimates based on previously published atmospheric measurements.

The 2006-2009 emissions distribution modeled from our data is $96 \pm 2 \%, 3 \pm 1 \%, 1 \pm 0.4 \%$, and $1 \pm 0.2 \%$ for the $30-$ $90^{\circ} \mathrm{N}, 0-30^{\circ} \mathrm{N}, 0-30^{\circ} \mathrm{S}$, and $30-90^{\circ} \mathrm{S}$ semi-hemispheres, respectively. EDGAR v4 estimates a similar NH:SH ratio for 2005 with $76 \%, 21 \%, 3 \%$, and $<1 \%$ for the same semihemispheres, respectively, but shifts emissions within the $\mathrm{NH}$ towards the tropics.

As with $\mathrm{CF}_{4}$ emissions, estimated $\mathrm{C}_{2} \mathrm{~F}_{6}$ emissions from UNFCCC data (Supplement 1, Table S1) are substantially lower than emissions based on AGAGE measurements. UNFCCC reported Annex I country emissions have declined by about $50 \%$ from $\sim 1.4 \mathrm{Gg} / \mathrm{yr}$ in 1990 to $\sim 0.8 \mathrm{Gg} / \mathrm{yr}$ in 2006, while AGAGE top-down emissions peaked in $\sim 2000$ at $\sim 3 \mathrm{Gg} / \mathrm{yr}$, and in 2006 were $\sim 2.3 \mathrm{Gg} / \mathrm{yr}$, similar to the 1990 value of $\sim 2.2 \mathrm{Gg} / \mathrm{yr}$. Again, the discrepancy is not surprising as non-Annex I countries with significant Al production (i.e., China, Brazil, South Africa, India, United Arab Emirates, Bahrain) and semiconductor/electronics manufacture (i.e., China, South Korea, Taiwan) are not included in the UNFCCC numbers, again demonstrating the need for global reporting.

Smelter technology-specific $\mathrm{Al}$ production emission ratios of $\mathrm{C}_{2} \mathrm{~F}_{6} / \mathrm{CF}_{4}$ (by mass) for 1990 and 2000 reported by IAI $(2001 ; 2003)$ are similar and industrial average emission ratios were $\sim 10 \% \mathrm{C}_{2} \mathrm{~F}_{6} / \mathrm{CF}_{4}$ (by mass) in 1990 and 2000 (see IPCC 2000 methodology in Zhihong et al., 2001). IPCC 2006 methodology recommends similar technology-specific emission ratios, except for SWPB (Side Worked Prebake), which is used to a smaller extent than other technologies (Harnisch et al., 2006; International Aluminium Institute, 2009a). Assuming that the $\mathrm{CF}_{4}$ and $\mathrm{C}_{2} \mathrm{~F}_{6}$ abundances measured by AGAGE in the early 1970s air samples stem from $\mathrm{Al}$ production and the natural background only, we deduce an emissions ratio of $10.2 \% \mathrm{C}_{2} \mathrm{~F}_{6} / \mathrm{CF}_{4}$ (by mass) from $\mathrm{Al}$ production. Lacking further information, we estimate later $\mathrm{Al}$ production $\mathrm{C}_{2} \mathrm{~F}_{6}$ emissions by multiplying the $\mathrm{Al}$ production $\mathrm{CF}_{4}$ emissions from the IAI Anode Effect surveys (Sect. 5.1) by this emission ratio. Resulting $\mathrm{Al}$ production $\mathrm{C}_{2} \mathrm{~F}_{6}$ emissions (Fig. 5) are lower than or similar to EDGAR v4 emissions from metal production (mostly Al). When EDGAR v4 non-metal production $\mathrm{C}_{2} \mathrm{~F}_{6}$ emissions ( $>97 \%$ from semiconductor/electronics manufacture) are added to our $\mathrm{Al}$ production $\mathrm{C}_{2} \mathrm{~F}_{6}$ emission estimates, the sums are lower than our global AGAGE top-down emission estimates.

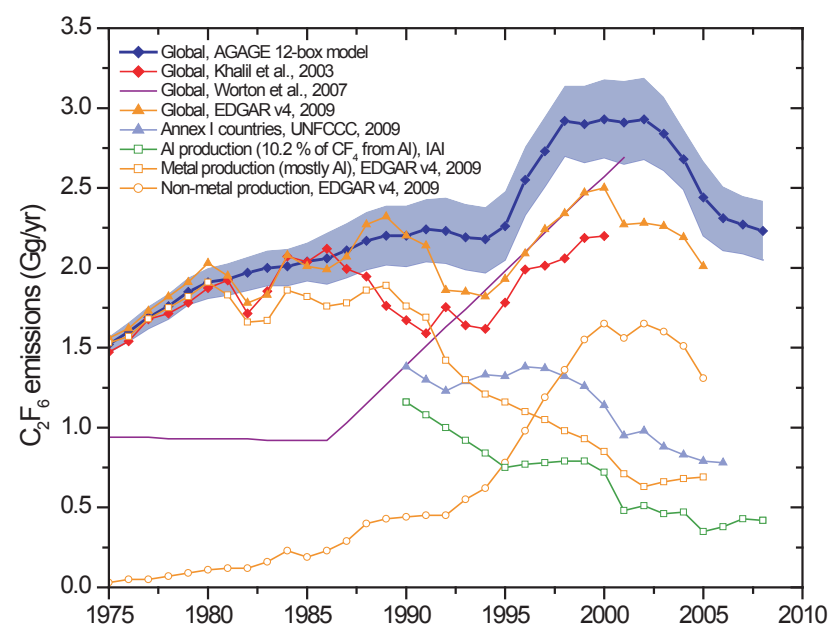

Fig. 5. Global $\mathrm{C}_{2} \mathrm{~F}_{6}$ emissions from the inversion of AGAGE atmospheric data with the AGAGE 2-D 12-box model compared to the emissions reported by Khalil et al. (2003), Worton et al. (2007), the EDGAR v4 (2009) emission database, and Annex I countries (UNFCCC, 2009, Table S1). Also shown are estimates of $\mathrm{C}_{2} \mathrm{~F}_{6}$ emissions from $\mathrm{Al}$ production (10.2\% of $\mathrm{Al}$-production $\mathrm{CF}_{4}$ emissions, IAI Anode Effect surveys), metal production (mostly Al, EDGAR v4, 2009), and non-metal production (EDGAR v4, 2009, >97\% semiconductor/electronics manufacture).

If the differences between global top-down AGAGE $\mathrm{CF}_{4}$ emissions and the sums of $\mathrm{Al}$ production $\mathrm{CF}_{4}$ emissions (IAI Anode Effect survey) and non-Al production emissions (EDGAR v4) were due to underestimated $\mathrm{Al}$ production $\mathrm{CF}_{4}$ emissions, the estimate for $\mathrm{Al}$ production $\mathrm{C}_{2} \mathrm{~F}_{6}$ emissions would need to be increased correspondingly by $10.2 \%$ (by mass) of the $\mathrm{CF}_{4}$ difference. The resulting sum of $\mathrm{Al}$ and non- $\mathrm{Al}$ production $\mathrm{C}_{2} \mathrm{~F}_{6}$ emissions would agree much better with AGAGE emissions from 2002 to 2005 (difference $\sim 0.2 \mathrm{Gg} / \mathrm{yr}$ ), but emissions from 1990 to 2001 would remain underestimated by $\sim 0.4 \mathrm{Gg} / \mathrm{yr}$, either because the assumptions are wrong and/or because EDGAR v4 semiconductor/electronics manufacture $\mathrm{C}_{2} \mathrm{~F}_{6}$ emissions from 1990 to 2001 are also underestimated.

\section{3 $\mathrm{CF}_{4}$ and $\mathrm{C}_{2} \mathrm{~F}_{6}$ equivalent $\mathrm{CO}_{2}$ emissions}

Recent IAI Anode Effect surveys report a sum of total $\mathrm{CF}_{4}$ and $\mathrm{C}_{2} \mathrm{~F}_{6} \quad \mathrm{CO}_{2}$-equivalent $\left(\mathrm{CO}_{2}\right.$-e) emissions using IPCC 2001 Second Assessment Report (SAR) global warming potentials (100-yr GWPs, Table 1) rather than separate $\mathrm{CF}_{4}$ and $\mathrm{C}_{2} \mathrm{~F}_{6}$ emissions or emission factors. Since the 2006 IAI Anode Effect survey (2008) total $\mathrm{CO}_{2}$-e emissions reported for 1990 and 1995 are $\sim 10 \%$ higher than in previous surveys, due to the change from IPCC 2000 to IPCC 2006 methodology, but $\mathrm{CO}_{2}$-e emissions reported for 2000 , 2004, and 2005 remain very similar. Correspondingly the $\mathrm{CO}_{2}$-equivalent sum of the $\mathrm{CF}_{4}$ and $\mathrm{C}_{2} \mathrm{~F}_{6} \mathrm{Al}$ production emissions discussed in the previous two sections, which are 
Table 7. Time averaged global $\mathrm{C}_{2} \mathrm{~F}_{6}$ emission estimates.

\begin{tabular}{|c|c|c|c|c|c|c|c|}
\hline & \multicolumn{7}{|c|}{ Time averaged $\mathrm{C}_{2} \mathrm{~F}_{6}$ emissions $(\mathrm{Gg} / \mathrm{yr})$ and percentages of AGAGE emissions } \\
\hline & 1975-1979 & 1980-1984 & $1985-1989$ & $1990-1994$ & 1995-1999 & 2000-2004 & $2005-2008$ \\
\hline This work & $1.7 \pm 0.1$ & $2.0 \pm 0.1$ & $2.1 \pm 0.1$ & $2.2 \pm 0.2$ & $2.7 \pm 0.2$ & $2.9 \pm 0.2$ & $2.3 \pm 0.1$ \\
\hline Harnisch et al. (1995) & \multicolumn{7}{|c|}{$2.0(96 \%)(1978-1995)$} \\
\hline Harnisch et al. (1996b) & \multicolumn{7}{|c|}{$1.9(88 \%)(1982-1996)$} \\
\hline Khalil et al. (2003) & $1.6(97 \%)$ & $1.9(96 \%)$ & $2.0(93 \%)$ & $1.7(75 \%)$ & $2.0(75 \%)$ & & \\
\hline Worton et al. (2007) & $0.9(55 \%)$ & $0.9(47 \%)$ & $1.1(50 \%)$ & $1.6(74 \%)$ & $2.2(82 \%)$ & & \\
\hline EDGAR 32/FT2000 & $1.2(70 \%)$ & $1.2(61 \%)$ & $1.2(56 \%)$ & $1.3(58 \%)$ & $2.2(83 \%)$ & & \\
\hline EDGAR v4 (2009) & $1.7(102 \%)$ & $1.9(98 \%)$ & $2.1(100 \%)$ & $2.0(90 \%)$ & $2.2(82 \%)$ & $2.3(80 \%)$ & $1.8(76 \%)^{\mathrm{a}}$ \\
\hline $\begin{array}{l}\text { IAI Anode Effect surveys ( } 10.2 \% \\
\left.\text { of } \mathrm{CF}_{4}\right) \text { (only } \mathrm{Al} \text { production) }\end{array}$ & & & & $1.0(46 \%)$ & $0.8(29 \%)$ & $0.5(18 \%)$ & $0.4(17 \%)$ \\
\hline UNFCCC Annex I countries $b$ & & & & $1.3(59 \%)$ & $1.3(49 \%)$ & $1.0(33 \%)$ & \\
\hline
\end{tabular}

a EDGAR v4 (2009) emission estimates have been extrapolated beyond 2005 based on the 2005-2004 difference.

b Based on PFC emission data collected by the UNFCCC process (United Nations Framework Convention on Climate Change, 2009).

based on $\mathrm{CF}_{4}$ and $\mathrm{C}_{2} \mathrm{~F}_{6}$ emission factors from previous IAI Anode Effect surveys, are 10-15\% lower until 1996 than the total $\mathrm{CO}_{2}$-e emissions directly listed in the latest IAI (2009a) survey. Afterwards the agreement is very good. If we add the (higher) $\mathrm{CO}_{2}$-e emissions listed in the latest IAI (2009a) survey to the EDGAR v4 $\mathrm{CO}_{2}$-e emissions estimated for non-metal production, the resulting sum remains significantly lower than the sum of global total AGAGE $\mathrm{CF}_{4}$ and $\mathrm{C}_{2} \mathrm{~F}_{6} \mathrm{CO}_{2}$-e emissions. From 1990 to 1992 the difference is $\sim 19$ million tonnes $\mathrm{CO}_{2}$-e emissions which corresponds to $\sim 2.9 \mathrm{Gg} \mathrm{CF}_{4}$ or $\sim 2.6 \mathrm{Gg} \mathrm{CF}_{4}$ and $\sim 0.3 \mathrm{Gg} \mathrm{C}_{2} \mathrm{~F}_{6}$ using the $\mathrm{C}_{2} \mathrm{~F}_{6} / \mathrm{CF}_{4}$ emission ratio of $10.2 \%$ from Sect. 5.2. Assuming that PFC emission from China were likely small in the early 1990s this could be explained by an underestimation of $\mathrm{CF}_{4}$ emissions in the IAI Anode Effect survey and/or by a significant underestimation of semiconductor/electronics manufacture emissions by EDGAR v4. Recently, the difference has grown substantially to $\sim 42$ million tonnes of $\mathrm{CO}_{2}$ e emissions in 2005 , which corresponds to $\sim 6.4 \mathrm{GgCF}_{4}$, or $\sim 5.6 \mathrm{Gg} \mathrm{CF}_{4}$ and $\sim 0.6 \mathrm{Gg} \mathrm{C}_{2} \mathrm{~F}_{6}$, similar to the $\mathrm{CF}_{4}$ emission gap of $\sim 6.1$. $\mathrm{Gg} \mathrm{CF}_{4}$ for 2005 described in Sect. 5.1, supporting the results in Sects. 5.1 and 5.2.

\section{$5.4 \mathrm{C}_{3} \mathrm{~F}_{8}$ emissions}

AGAGE global top-down $\mathrm{C}_{3} \mathrm{~F}_{8}$ emissions (Fig. 6) were $\sim 0.1 \mathrm{Gg} / \mathrm{yr}$ around 1975 , increased to $\sim 0.3 \mathrm{Gg} / \mathrm{yr}$ around 1992 , sharply increased to $\sim 1.1 \mathrm{Gg} / \mathrm{yr}$ in the mid-2000s and declined to $\sim 0.6 \mathrm{Gg} / \mathrm{yr}$ in 2008 . Khalil et al. (2003) reported $\sim 50 \%$ lower average top-down emissions (Table 8). Culbertson et al. (2004) reported very similar average emissions for 1982-1987 and 1992-1997, but substantially lower emissions for 1977-1982 and 1987-1992.

Only a small fraction of $\mathrm{C}_{3} \mathrm{~F}_{8}$ emissions estimated in this work are accounted for in the EDGAR v4 emission database (2009), $<1 \%$ in the 1970s and 1980s, $4-6 \%$ in the early 1990s, and $\sim 30 \%$ since 2003 (Fig. 6, Table 8).
The 2006-2009 emissions distribution modeled from our data is $98 \pm 0.4 \%, 1 \pm 1 \%,<0.1 \pm 0.2 \%$, and $<0.1 \pm 0.2 \%$ for the $30-90^{\circ} \mathrm{N}, 0-30^{\circ} \mathrm{N}, 0-30^{\circ} \mathrm{S}$, and $30-90^{\circ} \mathrm{S}$ semihemispheres, respectively. EDGAR v4 estimates a similar $\mathrm{NH}: \mathrm{SH}$ ratio for 2005 with $90 \%, 9 \%, 0.3 \%$, and $1 \%$ for the same semi-hemispheres, respectively, but shifts emissions within the NH towards the tropics.

Harnisch et al. (1998) estimated primary Al production $\mathrm{C}_{3} \mathrm{~F}_{8}$ emissions of $\sim 0.1 \pm 0.05 \mathrm{Gg} / \mathrm{yr}$, which are not taken into account by EDGAR v4. In the 1970s emissions from semiconductor/electronics manufacture and refrigeration/air conditioning were likely small. Assuming that the $\sim 0.1 \mathrm{Gg} / \mathrm{yr} \mathrm{C}_{3} \mathrm{~F}_{8}$ emissions estimated here for the $1970 \mathrm{~s}$ were related to $\mathrm{Al}$ production, an 1973 emissions factor of $0.0055 \mathrm{~kg} \mathrm{C}_{3} \mathrm{~F}_{8} /$ tonne $\mathrm{Al}$ and $\mathrm{a}_{3} \mathrm{~F}_{8} / \mathrm{CF}_{4}$ emission ratio of $0.48 \%$ (by mass) could be calculated using primary $\mathrm{Al}$ production data (similar to the estimation of $\mathrm{CF}_{4}$ and $\mathrm{C}_{2} \mathrm{~F}_{6}$ emissions). In 2008 the $0.48 \%$ (by weight) would contribute only $\sim 0.02 \mathrm{Gg} / \mathrm{yr}$, based on $\mathrm{Al}$ production $\mathrm{CF}_{4}$ emissions estimated from IAI Anode Effect surveys, or $\sim 0.05 \mathrm{Gg} / \mathrm{yr}$ if the total global $\mathrm{CF}_{4}$ emissions estimated from AGAGE measurements were from $\mathrm{Al}$ production. Both estimates are much lower than our $0.64 \mathrm{Gg}$ estimate for 2008. Either the $\mathrm{C}_{3} \mathrm{~F}_{8} / \mathrm{CF}_{4}$ emission ratio increased dramatically, which seems unlikely, or non-Al production $\mathrm{C}_{3} \mathrm{~F}_{8}$ sources must have gained rapid dominance. For example, $\mathrm{C}_{3} \mathrm{~F}_{8}$ has been proposed as an inert reaction medium, a dielectric, a propellant, a heat exchanger liquid, a deep-freezing agent, a fluorine component in $\mathrm{H} / \mathrm{F}$ lasers, an etching agent for $\mathrm{SiO}_{2}-$ coated silicon, as a component in breathing systems (von Halasz, 1978), and it is used in refrigerant mixtures $(20 \%$ in R403a, 39\% in R403b, 5\% in R412a, 9\% in R413a, 56\% in R509a). Clearly, the majority of $\mathrm{C}_{3} \mathrm{~F}_{8}$ emissions are unaccounted for. 
Table 8. Time averaged global $\mathrm{C}_{3} \mathrm{~F}_{8}$ emission estimates.

\begin{tabular}{|c|c|c|c|c|c|c|c|}
\hline \multirow[b]{2}{*}{ Global top-down estimates } & \multicolumn{7}{|c|}{ Time averaged $\mathrm{C}_{3} \mathrm{~F}_{8}$ emissions $(\mathrm{Gg} / \mathrm{yr})$ and percentages of AGAGE emissions } \\
\hline & $1975-1979$ & $1980-1984$ & $1985-1989$ & $1990-1994$ & 1995-1999 & 2000-2004 & $2005-2008$ \\
\hline This work & $0.12 \pm 0.01$ & $0.20 \pm 0.02$ & $0.26 \pm 0.03$ & $0.28 \pm 0.05$ & $0.65 \pm 0.06$ & $1.01 \pm 0.09$ & $0.76 \pm 0.05$ \\
\hline Khalil et al. (2003) & \multicolumn{2}{|c|}{$0.1(52 \%)(1978-1986)$} & \multicolumn{5}{|c|}{$0.3(59 \%)(1994-1997)$} \\
\hline Culbertson et al. (2004) & $\begin{array}{c}0.04(26 \%) \\
(1977-1982)\end{array}$ & $\begin{array}{c}0.21(90 \%) \\
(1983-1987)\end{array}$ & $\begin{array}{c}0.11(40 \%) \\
(1987-1992)\end{array}$ & $\begin{array}{r}0.48(1) \\
(1992-1\end{array}$ & & & \\
\hline EDGAR 32/FT2000 & $<0.01(0.5 \%)$ & $<0.01(0.5 \%)$ & $<0.01(0.6 \%)$ & $0.01(4 \%)$ & $0.12(18 \%)$ & & \\
\hline EDGAR v4 (2009) & $<0.01(0.6 \%)$ & $<0.01$ & $<0.01$ & $0.01(5 \%)$ & $0.12(19 \%)$ & $0.28(27 \%)$ & $0.28(37 \%)^{\mathrm{a}}$ \\
\hline UNFCCC Annex I countries ${ }^{b}$ & & & & $0.03(11 \%)$ & $0.05(7 \%)$ & $0.06(6 \%)$ & \\
\hline
\end{tabular}

a EDGAR v4 (2009) emission estimates have been extrapolated beyond 2005 keeping 2005 refrigeration/air conditioning emissions (similar to 2000-2005) and extrapolating semiconductor/electronics and other F-gas use emissions beyond 2005 based on the 2005-2004 difference.

${ }^{\mathrm{b}}$ Based on PFC emission data collected by the UNFCCC process (United Nations Framework Convention on Climate Change, 2009).

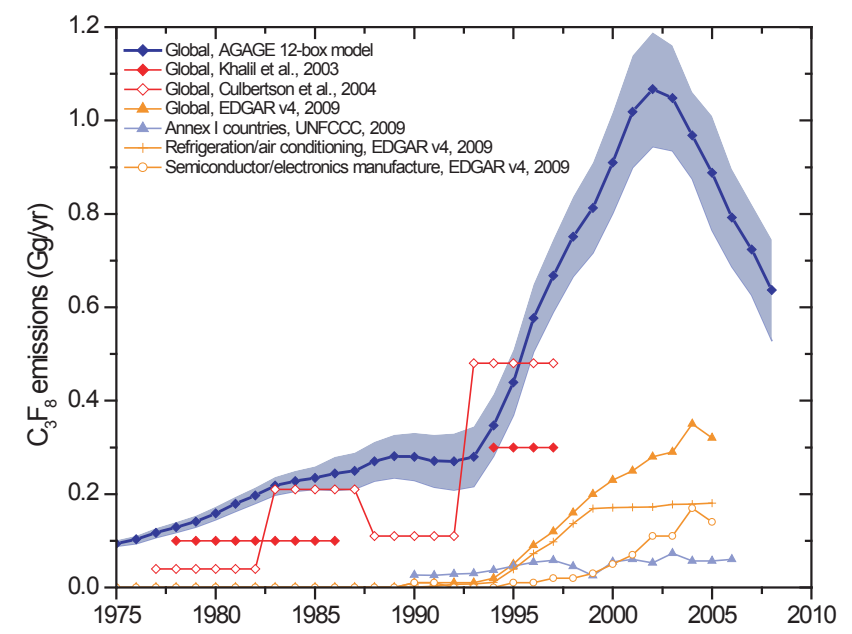

Fig. 6. Global $\mathrm{C}_{3} \mathrm{~F}_{8}$ emissions from the inversion of AGAGE atmospheric data with the AGAGE 2-D 12-box model compared to emissions reported by Khalil et al. (2003), Culbertson et al. (2004), the EDGAR v4 (2009) emission database, and Annex I countries (UNFCCC, 2009, Table S1). Also shown are EDGAR v4 emission estimates for refrigeration/air conditioning and semiconductor/electronics manufacture.

Like $\mathrm{CF}_{4}$ and $\mathrm{C}_{2} \mathrm{~F}_{6}$ emissions, $\mathrm{C}_{3} \mathrm{~F}_{8}$ emissions from UNFCCC data (Supplement 1, Table S1) are substantially lower than the top-down emissions based on AGAGE measurements. UNFCCC reported emissions have increased from $\sim 0.03 \mathrm{Gg} / \mathrm{yr}$ in 1990 to $\sim 0.06 \mathrm{Gg} / \mathrm{yr}$ in 2006 , while actual emissions were $\sim 8-32$ times higher. Given the lack of knowledge about $\mathrm{C}_{3} \mathrm{~F}_{8}$ emission sources and source strengths and the fact that many non-Annex I countries with significant industrial activity such as $\mathrm{Al}$ production and semiconductor/electronic manufacture are not included in the UNFCCC data, the discrepancy is not surprising, yet again demonstrating the need for global reporting.
Total global $\mathrm{C}_{3} \mathrm{~F}_{8}$ emissions from all sources expressed as $\mathrm{CO}_{2}$-e emissions add $\sim 0.5 \%$ in the early 1970 s, $\sim 8 \%$ in 2002 and 2003, and $\sim 5 \%$ in 2008 to the global total $\mathrm{CF}_{4}$ and $\mathrm{C}_{2} \mathrm{~F}_{6} \mathrm{CO}_{2}$-e emissions discussed in Sect. 5.3 (SAR $\left.\mathrm{GWP}_{100} \mathrm{~s}\right)$.

\section{Summary and conclusions}

We have presented measurements of the perfluorocarbons (PFCs) $\mathrm{CF}_{4}, \mathrm{C}_{2} \mathrm{~F}_{6}$, and $\mathrm{C}_{3} \mathrm{~F}_{8}$ with much improved accuracies of $\sim 1-2 \%$ on calibration scales developed for the Advanced Global Atmospheric Gases Experiment (AGAGE). The measurements have been made with the "Medusa" trace gas analytical system which achieves excellent precisions for the PFCs. We have determined long-term baseline growth rates and interhemispheric gradients in both hemispheres for $\mathrm{CF}_{4}, \mathrm{C}_{2} \mathrm{~F}_{6}$, and $\mathrm{C}_{3} \mathrm{~F}_{8}$ over three decades, based on measurements of archived air and in situ real-time atmospheric measurements. We find that the abundances of $\mathrm{CF}_{4}$ are $\sim 6-$ $10 \%$ lower than previously reported, an important finding for this long-lived and potent greenhouse gas. The pre-industrial backgrounds were measured in air extracted from Greenland ice and Antarctic firn.

Global inversions (AGAGE 2-D 12-box model) were used to estimate global $\mathrm{CF}_{4}, \mathrm{C}_{2} \mathrm{~F}_{6}$, and $\mathrm{C}_{3} \mathrm{~F}_{8}$ source strength over the last three decades. The authors of the Representative Concentration Pathways (RCP) emission scenarios of the Coupled Model Intercomparison Project Phase 5 (CMIP5) for the upcoming Fifth Assessment Report (AR5) had access to our preliminary results (M. Meinshausen, personal communication, 2009). Past and present RCP $\mathrm{CF}_{4}$ and $\mathrm{C}_{2} \mathrm{~F}_{6}$ emissions are in reasonable agreement with AGAGE top-down emissions and future emissions are similar or drop steeply (http://www.iiasa.ac.at/web-apps/ tnt/RcpDb/dsd?Action=htmlpage\&page=about), while many IPCC Second Assessment Report (SAR) emission scenarios started out with significantly different emissions 
and predicted very high future $\mathrm{CF}_{4}$ and $\mathrm{C}_{2} \mathrm{~F}_{6}$ emissions (Nakićenović et al., 2000). No $\mathrm{C}_{3} \mathrm{~F}_{8}$ emission scenarios exist.

EDGAR v4 emissions and top-down emissions estimated here by AGAGE agree after $\sim 1990$ for $\mathrm{CF}_{4}$ and before $\sim 1992$ for $\mathrm{C}_{2} \mathrm{~F}_{6}$, but at other times EDGAR v4 emissions are too low. EDGAR v4 provides valuable information for atmospheric research, but being a hybrid of bottom-up methodologies and top-down estimates based on previously published atmospheric measurements, it is unclear how $\mathrm{CF}_{4}$ and $\mathrm{C}_{2} \mathrm{~F}_{6}$ emission components were derived and how certain they are. EDGAR v4 $\mathrm{C}_{3} \mathrm{~F}_{8}$ emissions are underestimated by 100 to 200-times in the 1970s and 1980s and by 3 to 4 times since 1999. $\mathrm{C}_{3} \mathrm{~F}_{8}$ emissions from $\mathrm{Al}$ production, not considered in EDGAR v4, can only explain a small fraction of the difference. The industrial production and usage of $\mathrm{C}_{3} \mathrm{~F}_{8}$ should be investigated to find the missing emission source(s).

UNFCCC $\mathrm{CF}_{4}$ and $\mathrm{C}_{2} \mathrm{~F}_{6}$ emission estimates are only $\sim 30-70 \%$ of global AGAGE top-down emissions, since nonAnnex I countries with significant $\mathrm{Al}$ production (i.e., China, Brazil, South Africa, India, United Arab Emirates, Bahrain) and with semiconductor/electronics manufacture (i.e., China, South Korea, Taiwan) are not included in UNFCCC data to date. UNFCCC $\mathrm{C}_{3} \mathrm{~F}_{8}$ emission estimates are 8-32 times lower than AGAGE top-down emissions.

The sum of $\mathrm{CF}_{4}$ emissions estimated from International Aluminium Institute (IAI) Anode Effect surveys and EDGAR v4 non-metal production emissions are $\sim 3-5 \mathrm{Gg} / \mathrm{yr}$ too low from 1990 to 1992 , and are $\sim 6 \mathrm{Gg} / \mathrm{yr}$ too low in 2005. Possible explanations are that IPCC methodologies as applied by IAI lead to an underestimation of $\mathrm{Al}$ production $\mathrm{CF}_{4}$ emissions, especially from China where only a few aluminum smelters have been surveyed, and/or that semiconductor/electronics manufacture $\mathrm{CF}_{4}$ emissions in EDGAR v4 are significantly underestimated, but with our current knowledge it is impossible to determine which is true. Unfortunately, the report of the World Semiconductor Council (WSC) on the voluntary perfluorocompound emissions reduction program of semiconductor manufacturers lists only relative perfluorocompound emissions and does not explain how they were measured, estimated, and/or verified. The report gives no information how the emissions of specific perfluorocarbons such as $\mathrm{CF}_{4}$ or $\mathrm{C}_{2} \mathrm{~F}_{6}$ have evolved and whether the use of the phrase perfluorocompounds instead of perfluorocarbons means that $\mathrm{SF}_{6}$ and $\mathrm{NF}_{3}$ are included in the sum, which would further complicate the interpretation of WSC data. The IAI Anode Effect surveys on PFC emissions from $\mathrm{Al}$ production contain many details and are based on IPCC methodology, but recent IAI reports do not list individual $\mathrm{CF}_{4}$ and $\mathrm{C}_{2} \mathrm{~F}_{6}$ emissions or emission factors, which also complicates the use of IAI data. Furthermore, recently Maltais et al. (2010) discovered significant PFC emissions during the startup of reduction cells which may not be accounted for by IPCC methodology. The EDGAR database does not provide all details necessary to understand how their PFC emis- sion estimates are calculated or apportioned among source categories.

The significant discrepancies between UNFCCC, EDGAR, and IAI PFC emission estimates and global topdown emission estimates based on AGAGE measurements, the lack of details in the WSC report and the EDGAR database and possible uncertainties in IPCC methodologies, emphasize the need for more accurate, transparent, and complete global emissions reporting, and for verification with atmospheric measurements to assess the emissions of these long-lived and potent greenhouse gases. Our understanding of PFC emissions from $\mathrm{Al}$ production, semiconductor/electronics manufacture, and possibly other sources needs to be improved since the PFCs contribute significantly to the greenhouse gas budget of countries with large Al production (Isaksen et al., 1992) and semiconductor/electronics industries (Cook, 1995), and alter the radiative budget of the atmosphere essentially permanently. A combined effort by IAI, WSC, global PFC suppliers, and EDGAR to improve estimates of PFC emissions would be very valuable. To allow direct comparison with atmospheric observations individual $\mathrm{CF}_{4}$ and $\mathrm{C}_{2} \mathrm{~F}_{6}$ emissions and emission factors should be reported. High-frequency in situ $\mathrm{CF}_{4}, \mathrm{C}_{2} \mathrm{~F}_{6}$, and $\mathrm{C}_{3} \mathrm{~F}_{8}$ measurements in the vicinity of important regional sources such as China, in combination with advanced 3-D modeling are needed to quantify regional emissions and to untangle the flux contributions from $\mathrm{Al}$ production and non-Al production sources.

\section{Supplementary material related to this article is available online at: http://www.atmos-chem-phys.net/10/5145/2010/ acp-10-5145-2010-supplement.pdf.}

Acknowledgements. Development of the Medusa GC/MS systems, calibrations, and measurements were carried out as part of the international AGAGE research program and supported by the NASA Upper Atmospheric Research Program in the US with grants NNX07AE89G to MIT, NNX07AF09G and NNX07AE87G to SIO, Defra and NOAA in the UK, CSIRO and the Australian Government Bureau of Meteorology in Australia. We thank J. P. Severinghaus (SIO) for the Megadunes firn samples from Antarctica, J. E. Shields (SIO) for an air-age estimate of the deepest and oldest Megadunes firn air samples used in this work, V. V. Petrenko and J. P. Severinghaus (SIO) for the ancient NH ice samples from the Pâkitsoq site in Greenland. We especially thank E. J. Dlugokencky, J. W. Elkins, B. D.Hall, and S. A. Montzka (NOAA/GMD), C. D. Keeling (deceased) and R. F. Keeling (SIO), N. Schmidbauer, O. Hermansen, C. R. Lunder (NILU), and R. C. Rhew (UCB) for air samples. We thank R. A. Rasmussen and the Oregon Graduate Institute (OGI) for originally collecting the Cape Meares Northern Hemispheric samples which were provided by NOAA/GMD, NILU, and CSIRO. We are indebted to the staff at the AGAGE sites for their continuing contributions to produce high quality measurements of atmospheric trace gases. In particular, we thank G. Spain (Mace Head), R. Dickau (Trinidad Head), 
P. Sealy (Ragged Point), M. C. Cunningham (Cape Matatula), C. G. Rickard, and J. Z. Ward (Cape Grim). In addition, we thank M. Leist (CSIRO) for his excellent technical support of the Cape Grim Medusa system. We are especially thankful to R. Knapp, J. Marks, and C. Bayliss (International Aluminium Institute, IAI), M. Ison (Australian Aluminium Council, AAC) and the two anonymous reviewers for their insightful comments and reviews which contributed to the improvement of this manuscript.

Edited by: J. Kaiser

\section{References}

Abrahamson, D.: Aluminium and global warming, Nature, 356, p. 484, doi:10.1038/356484a0, 1992.

Aoki, N. and Makide, Y.: Precise determination of the atmospheric $\mathrm{CF}_{4}$ concentration by using natural $\mathrm{Kr}$ in the atmosphere as an internal reference in the preconcentration/GC/MS analysis, Chem. Lett., 33, 1634-1635, 2004.

Aoki, N. and Makide, Y.: The concentration of krypton in the atmosphere - Its revision after half a century, Chem. Lett., 34, 13961397, 2005.

Cicerone, R. J.: Atmospheric Carbon Tetrafluoride - Nearly InertGas, Science, 206, 59-61, 1979.

Clerbaux, C., Cunnold, D. M., Anderson, J., Engel, A., Fraser, P. J., Mahieu, E., Manning, A., Miller, J., Montzka, S. A., Nassar, R., Prinn, R., Reimann, S., Rinsland, C. P., Simmonds, P., Verdonik, D., Weiss, R., Wuebbles, D., and Yokouchi, Y.: Long-Lived Compounds, Chapter 1, in: Scientific Assessment of Ozone Depletion: 2006, Global Ozone Research and Monitoring Project-Report No. 50, 572 pp., World Meteorological Organization, Geneva, Switzerland, 2007.

Cook, E.: Lifetime Commitments: Why climate policy-makers can't afford to overlook fully fluorinated compounds, World Resource Institute, Washington, USA, 2, 1995.

Courville, Z. R., Albert, M. R., Fahnestock, M. A., Cathles, L. M., and Shuman, C. A.: Impacts of an accumulation hiatus on the physical properties of firn at a low-accumulation polar site, J. Geophys. Res., 112, F02030, doi:02010.01029/02005JF000429, 2007.

Culbertson, J. A., Prins, J. M., and Grimsrud, E. P.: Improvements in the detection and analysis of $\mathrm{CF}_{3}$-containing compounds in the background atmosphere by gas chromatography-high-resolution mass spectrometry, J. Chromatogr., 903, 261-265, 2000.

Culbertson, J. A., Prins, J. M., Grimsrud, E. P., Rasmussen, R. A., Khalil, M. A. K., and Shearer, M. J.: Observed trends for $\mathrm{CF}_{3}$-containing compounds in background air at Cape Meares, Oregon, Point Barrow, Alaska, and Palmer Station, Antarctica, Chemosphere, 55, 1109-1119, 2004.

Cunnold, D. M., Prinn, R. G., Rasmussen, R. A., Simmonds, P. G., Alyea, F. N., Cardelino, C. A., Crawford, A. J., Fraser, P. J., and Rosen, R. D.: The Atmospheric Lifetime Experiment, 3. Lifetime Methodology and Application to 3 Years of $\mathrm{CFCl}_{3}$ Data, J. Geophys. Res., 88, 8379-8400, 1983.

Cunnold, D. M., Fraser, P. J., Weiss, R. F., Prinn, R. G., Simmonds, P. G., Miller, B. R., Alyea, F. N., and Crawford, A. J.: Global Trends and Annual Releases of $\mathrm{CCl}_{3} \mathrm{~F}$ and $\mathrm{CCl}_{2} \mathrm{~F}_{2}$ Estimated from ALE/GAGE and Other Measurements from July 1978 to June 1991, J. Geophys. Res., 99, 1107-1126, 1994.
Cunnold, D. M., Steele, L. P., Fraser, P. J., Simmonds, P. G., Prinn, R. G., Weiss, R. F., Porter, L. W., O'Doherty, S., Langenfelds, R. L., Krummel, P. B., Wang, H. J., Emmons, L., Tie, X. X., and Dlugokencky, E. J.: In situ measurements of atmospheric methane at GAGE/AGAGE sites during 1985-2000 and resulting source inferences, J. Geophys. Res., 107(D14), 4225, doi:10.1029/2001JD001226, 2002.

Deeds, D. A., Vollmer, M. K., Kulongoski, J. T., Miller, B. R., Mühle, J., Harth, C. M., Izbicki, J. A., Hilton, D. R., and Weiss, R. F.: Evidence for crustal degassing of $\mathrm{CF}_{4}$ and $\mathrm{SF}_{6}$ in Mojave Desert groundwaters, Geochim. Cosmochim. Acta, 72, 999 1013, 2008.

EDGAR: European Commission, Joint Research Centre (JRC)/Netherlands Environmental Assessment Agency (PBL). Emission Database for Global Atmospheric Research (EDGAR), release version 4.0., online available at: http://edgar.jrc.ec.europa.eu, 2009.

Fabian, P., Borchers, R., Penkett, S. A., and Prosser, N. J. D.: Halocarbons in the stratosphere, Nature, 294, 733-735, 1981.

Fabian, P., Borchers, R., Kruger, B. C., and Lal, S.: $\mathrm{CF}_{4}$ and $\mathrm{C}_{2} \mathrm{~F}_{6}$ in the Atmosphere, J. Geophys. Res., 92, 9831-9835, 1987.

Fabian, P., Borchers, R., Leifer, R., Subbaraya, B. H., Lal, S., and Boy, M.: Global stratospheric distribution of halocarbons, Atmos. Environ., 30, 1787-1796, 1996.

Forster, P., Ramaswamy, V., Artaxo, P., Berntsen, T., Betts, R., Fahey, D. W., Haywood, J., Lean, J., Lowe, D. C., Myhre, G., Nganga, J., Prinn, R., Raga, G., Schulz, M., and Dorland, R. V.: Changes in Atmospheric Constituents and in Radiative Forcing, in: Climate Change 2007: The Physical Science Basis. Contribution of Working Group I to the Fourth Assessment Report of the Intergovernmental Panel on Climate Change, edited by: Solomon, S., Qin, D., Manning, M., Chen, Z., Marquis, M., Averyt, K. B., M.Tignor, and Miller, H. L., Cambridge University Press, Cambridge, United Kingdom and New York, NY, USA, 2007.

Gassmann, M.: Freon-14 in Pure Krypton and in Atmosphere, Naturwissenschaften, 61, 127-127, 1974.

Goldman, A., Murcray, D. G., Murcray, F. J., Cook, G. R., Vanallen, J. W., Bonomo, F. S., and Blatherwick, R. D.: Identification of the V3-Vibration-Rotation Band of $\mathrm{CF}_{4}$ in Balloon-Borne Infrared Solar Spectra, Geophys. Res. Lett., 6, 609-612, 1979.

Harnisch, J., Borchers, R., and Fabian, P.: Estimation of tropospheric trends (1980-1995) for $\mathrm{CF}_{4}$ and $\mathrm{C}_{2} \mathrm{~F}_{6}$ from stratospheric data, Proc. SPIE, 2506, 384-393, doi:10.1117/12.221039, 1995.

Harnisch, J., Borchers, R., Fabian, P., Gaggeler, H. W., and Schotterer, U.: Effect of natural tetrafluoromethane, Nature, 384, p. 32, 1996a.

Harnisch, J., Borchers, R., Fabian, P., and Maiss, M.: Tropospheric trends for $\mathrm{CF}_{4}$ and $\mathrm{C}_{2} \mathrm{~F}_{6}$ since 1982 derived from $\mathrm{SF}_{6}$ dated stratospheric air, Geophys. Res. Lett., 23, 1099-1102, 1996 b.

Harnisch, J. and Eisenhauer, A.: Natural $\mathrm{CF}_{4}$ and $\mathrm{SF}_{6}$ on Earth, Geophys. Res. Lett., 25, 2401-2404, 1998.

Harnisch, J., Wing, I. S., Jacoby, H. D., and Prinn, R. G.: Primary Aluminum Production: Climate Policy, Emissions and Costs, Massachusetts Institute of Technology, Report \#44, 1998.

Harnisch, J., Borchers, R., Fabian, P., and Maiss, M.: $\mathrm{CF}_{4}$ and the age of mesospheric and polar vortex air, Geophys. Res. Lett., 26 , 295-298, 1999.

Harnisch, J.: Atmospheric perfluorocarbons: sources and concen- 
trations, in: Non- $\mathrm{CO}_{2}$ greenhouse gases: scientific understanding, control and implementation, edited by: van Ham, J., Baede, A., Meyer, L., and Ybema, R., Kluwer Academic Publishers, Netherlands, 205-210, 2000.

Harnisch, J., Frische, M., Borchers, R., Eisenhauer, A., and Jordan, A.: Natural fluorinated organics in fluorite and rocks, Geophys. Res. Lett., 27, 1883-1886, 2000.

Harnisch, J., Agyemang-Bonsu, W. K., Katima, J. H. Y., Rosland, A., Marks, J., Born, M. F., Green, L., Kvande, H., Martchek, K., and Rand, S.: Volume 3, Industrial Processes and Product Use, Chapter 4.4, Metal Industry Emissions, Primary aluminium production, in: 2006 IPCC Guidelines for National Greenhouse Gas Inventories, IGES, Hayama, Japan, 2006.

Holliday, R. D. and Henry, J. L.: Anode Polarization Fluorocarbon Formation in Aluminum Reduction Cells, J. Ind. Eng. Chem., 51, 1289-1292, 1959.

Hurley, M. D., Wallington, T. J., Buchanan, G. A., Gohar, L. K., Marston, G., and Shine, K. P.: IR spectrum and radiative forcing of $\mathrm{CF}_{4}$ revisited, J. Geophys. Res., 110, D02102, doi:10.1029/2004JD005201, 2005.

International Aluminium Institute: Anode effect survey 1994-1997 and Perfluorocarbon Compounds Emissions Survey 1990-1997, International Aluminium Institute, London, 2000.

International Aluminium Institute: Perfluorocarbon Emissions Reduction Programme 1990-2000, International Aluminium Institute, London, 2001.

International Aluminium Institute: The International Aluminium Institute('s) Report on the Aluminium Industry's Global Perfluorocarbon Gas Emissions Reduction Programme - Results of the 2001-2006 Anode Effect Survey, International Aluminium Institute, London, 2003-2008.

International Aluminium Institute: The International Aluminium Institute Report on the Aluminium Industry's Global Per?uorocarbon Gas Emissions Reduction Programme - Results of the 2008 Anode Effect Survey, International Aluminium Institute, London, 2009a.

International Aluminium Institute: The International Aluminium Institute Report on the Aluminium Industrys Global Perfuorocarbon Gas Emissions Reduction Programme - Results of the 2007 Anode Effect Survey, International Aluminium Institute, London, 2009b.

International Primary Aluminium Institute: Anode effect and PFC emission survey 1990-1993, International Primary Aluminium Institute, London, 1996.

Isaksen, I. S. A., Brühl, C., Molina, M., Schiff, H., Shine, K., and Stordal, F.: An assessment of the role of $\mathrm{CF}_{4}$ and $\mathrm{C}_{2} \mathrm{~F}_{6}$ as greenhouse gases, Center for International Climate and Environmental Research, Oslo, Policy Note 1992, 6, 1992.

Jain, A. K., Briegleb, B. P., Minschwaner, K., and Wuebbles, D. J.: Radiative forcings and global warming potentials of 39 greenhouse gases, J. Geophys. Res., 105, 20773-20790, 2000.

Khalil, M. A. K. and Rasmussen, R. A.: Atmospheric Carbontetrafluoride $\left(\mathrm{CF}_{4}\right)$ : Sources and Trends, Geophys. Res. Lett., 12, 671-672, 1985.

Khalil, M. A. K., Rasmussen, R. A., Culbertson, J. A., Prins, J. M., Grimsrud, E. P., and Shearer, M. J.: Atmospheric perfluorocarbons, Environ. Sci. Technol., 37, 4358-4361, 2003.

Kranz, R.: Organische Fluor-Verbindungen in den Gaseinschlussen der Wolsendorfer Flussspate, Naturwissenschaften, 53, 593-600,
1966.

Krummel, P. B., Langenfelds, R., Fraser, P. J., Steele, L. P., and Porter, L. W.: Archiving of Cape Grim air, in: Baseline Atmospheric Program Australia 2005-2006, edited by: Cainey, J. M., Derek, N., and Krummel, P. B., Australian Bureau of Meteorology and CSIRO Marine and Atmospheric Research, Melbourne, Australia, 55-57, 2007.

Lide, D. R.: CRC Handbook of Chemistry and Physics, 1993-1994, 74 th ed., CRC Press Inc., Boca Raton, USA, 1993.

Lide, D. R.: CRC Handbook of Chemistry and Physics, 2003-2004, CRC Press Inc., Boca Raton, USA, 2003.

Maiss, M., Steele, L. P., Francey, R. J., Fraser, P. J., Langenfelds, R. L., Trivett, N. B. A., and Levin, I.: Sulfur hexafluoride - A powerful new atmospheric tracer, Atmos. Environ., 30, 16211629, 1996.

Maltais, J.-N., Ross, J., Marcoux, A., and Gaudreault, G.: Application of a Method for the Determination of PFC Emissions during Aluminum Pot Start-up, in: Light Metals 2010, edited by: Johnson, J. A., 2010

Miller, B. R., Weiss, R. F., Salameh, P. K., Tanhua, T., Greally, B. R., Mühle, J., and Simmonds, P.: Medusa: A Sample Preconcentration and GC/MS Detector System for in Situ Measurements of Atmospheric Trace Halocarbons, Hydrocarbons, and Sulfur Compounds, Anal. Chem., 80, 701536-701545, doi:10.1021/ac702084k, 2008.

Morris, R. A., Miller, T. M., Viggiano, A. A., Paulson, J. F., Solomon, S., and Reid, G.: Effects of electron and ion reactions on atmospheric lifetimes of fully fluorinated compounds, J. Geophys. Res., 100, 1287-1294, 1995.

Nakićenović, N., Alcamo, J., Davis, G., de Vries, B., Fenhann, J., Gaffin, S., Gregory, K., Grübler, A., Jung, T. Y., Kram, T., La Rovere, E. L., Michaelis, L., Mori, S., Morita, T., Pepper, W., Pitcher, H., Price, L., Raihi, K., Roehrl, A., Rogner, H.-H., Sankovski, A., Schlesinger, M., Shukla, P., Smith, S., Swart, R., van Rooijen, S., Victor, N., and Dad, Z.: IPCC Special Report on Emissions Scenarios, 599, 2000.

Olivier, J. G. J. and Berdowski, J. J. M.: Global emissions sources and sinks, in: The Climate System, edited by: Berdowski, J., Guicherit, R., and Heij, B. J., A.A. Balkema Publishers/Swets \& Zeitlinger Publishers, Lisse, The Netherlands, 33-78, 2001.

Penkett, S. A., Prosser, N. J. D., Rasmussen, R. A., and Khalil, M. A. K.: Atmospheric Measurements of $\mathrm{CF}_{4}$ and Other Fluorocarbons Containing the $\mathrm{CF}_{3}$ Grouping, J. Geophys. Res., 86, 5172-5178, 1981.

Petrenko, V. V., Severinghaus, J. P., Brook, E. J., Reeh, N., and Schaefer, H.: Gas records from the West Greenland ice margin covering the Last Glacial Termination: a horizontal ice core, Quaternary Sci. Rev., 25, 865-875, 2006.

Petrenko, V. V., Severinghaus, J. P., Brook, E. J., Mühle, J., Headly, M., Harth, C. M., Schaefer, H., Reeh, N., Weiss, R. F., Lowe, D., and Smith, A. M.: A novel method for obtaining very large ancient air samples from ablting glacial ice for analyses of methane radiocarbon, J. Glaciol., 54, 233-244, 2008.

Petrenko, V. V., Smith, A. M., Brook, E. J., Lowe, D., Riedel, K., Brailsford, G., Hua, Q., Schaefer, H., Reeh, N., Weiss, R. F., Etheridge, D., and Severinghaus, J. P.: ${ }^{14} \mathrm{CH}_{4}$ Measurements in Greenland Ice: Investigating Last Glacial Termination $\mathrm{CH}_{4}$ Sources, Science, 324, 1168506-1168508, doi:10.1126/science.1168909, 2009. 
Prinn, R. G.: Measurement equation for trace chemicals in fluids and solution of its inverse, in: Inverse Methods in Global Biogeochemical Cycles, Geophys. Monogr. Ser., edited by: Kasibhatla, P., Heimann, M., Rayner, P., Mahowald, N., Prinn, R. G., and Hartley, D. E., American Geophysical Union, Washington, DC, 3-18, 2000.

Prinn, R. G., Weiss, R. F., Fraser, P. J., Simmonds, P. G., Cunnold, D. M., Alyea, F. N., O'Doherty, S., Salameh, P., Miller, B. R., Huang, J., Wang, R. H. J., Hartley, D. E., Harth, C., Steele, L. P., Sturrock, G., Midgley, P. M., and McCulloch, A.: A history of chemically and radiatively important gases in air deduced from ALE/GAGE/AGAGE, J. Geophys. Res., 105, 17751-17792, 2000.

Prinn, R. G., Huang, J., Weiss, R. F., Cunnold, D. M., Fraser, P. J., Simmonds, P. G., McCulloch, A., Harth, C., Salameh, P., O’Doherty, S., Wang, R. H. J., Porter, L., and Miller, B. R.: Evidence for substantial variations of atmospheric hydroxyl radicals in the past two decades, Science, 292, 1882-1888, 2001.

Rasmussen, R. A., Penkett, S. A., and Prosser, N.: Measurement of Carbon Tetrafluoride in the Atmosphere, Nature, 277, 549-551, 1979.

Ravishankara, A. R., Solomon, S., Turnipseed, A. A., and Warren, R. F.: Atmospheric lifetimes of long-lived halogenated species, Science, 259, 194-199, 1993.

Reeh, N., Oerter, H., Letreguilly, A., Miller, H., and Hubberten, H. W.: A New, Detailed Ice-Age Oxygen-18 Record from the IceSheet Margin in Central West Greenland, Global Planet. Change, 90, 373-383, 1991.

Rinsland, C. P., Mahieu, E., Zander, R., Nassar, R., Bernath, P., Boone, C., and Chiou, L. S.: Long-term stratospheric carbon tetrafluoride $\left(\mathrm{CF}_{4}\right)$ increase inferred from 1985-2004 infrared space-based solar occultation measurements, Geophys. Res. Lett., 33, L02808, doi:02810.01029/02005GL024709, 2006.

Schwander, J., Barnola, J. M., Andrie, C., Leuenberger, M., Ludin, A., Raynaud, D., and Stauffer, B.: The Age of the Air in the Firn and the Ice at Summit, Greenland, J. Geophys. Res., 98, 28312838, 1993.

Severinghaus, J. P. and Battle, M. O.: Fractionation of gases in polar ice during bubble close-off: New constraints from firn air $\mathrm{Ne}$, $\mathrm{Kr}$ and Xe observations, Earth Planet. Sci. Lett., 244, 474-500, 2006.

Severinghaus, J. P., Albert, M. R., Courville, Z. R., Fahnestock, M. A., Kawamura, K., Montzka, S. A., Mühle, J., Scambos, T. A., Shields, E. J., Shuman, C. A., Suwa, M., Tans, P., and Weiss, R. F.: Deep air convection in the firn at a zero-accumulation site, central Antarctica, Earth Planet. Sci. Lett., 293, 359-367, doi:10.1016/j.eps1.2010.03.003, 2010.

Shields, J. E., Mühle, J., Severinghaus, J. P., and Weiss, R. F.: Reconstructing Atmospheric Histories of Halogenated Compounds to Preindustrial Times Using Antarctic Firn Air, Eos Trans. AGU, 88, Fall Meet. Suppl., Abstract A44B-06, 2007.
Symonds, R. B., Rose, W. I., and Reed, M. H.: Contribution of Cland F-bearing gases to the atmosphere by volcanos, Nature, 334, 415-418, 1988.

Taberaux, A. T.: Anode Effects, PFCs, Global Warming, and the Aluminum-Industry, J. Miner. Met. Mater. Soc., 46, 30-34, 1994.

Tsai, W.-T., Chen, H.-P., and Hsien, W.-Y.: A review of uses, environmental hazards and recovery/recycle technologies of perfluorocarbons (PFCs) emissions from the semiconductor manufacturing processes, J. Loss Prev. Process Ind., 15, 65-75, 2002.

United Nations Framework Convention on Climate Change: http://unfccc.int/national_reports/annex_i_ghg_inventories/ national_inventories_submissions/items/4771.php, 2009.

US Geological Survey: Minerals Yearbook, edited by: Plunkert, P. A. and Bray, E. L., US. Geological Survey, Washington, DC, 1932-2009, online available at: http://minerals.usgs.gov/ minerals/pubs/commodity/aluminum/, 2010.

Victor, D. G. and MacDonald, G. J.: A model for estimating future emissions of sulfur hexafluoride and perfluorocarbons, Climatic Change, 42, 633-662, 1999.

von Halasz, S. P.: Process for the manufacture of octafluoropropane, US Patent 4, 158023, 1978.

Weiss, R. F., Mühle, J., Salameh, P. K., and Harth, C. M.: Nitrogen trifluoride in the global atmosphere, Geophys. Res. Lett., 35, L20821, doi:20810.21029/22008GL035913, 2008.

Worton, D. R., Sturges, W. T., Gohar, L. K., Shine, K. P., Martinerie, P., Oram, D. E., Humphrey, S. P., Begley, P., Gunn, L., Barnola, J.-M., Schwander, J., and Mulvaney, R.: Atmospheric Trends and Radiative Forcings of $\mathrm{CF}_{4}$ and $\mathrm{C}_{2} \mathrm{~F}_{6}$ Inferred from Firn Air, Environ. Sci. Technol., 41, 2184-2189, doi:2110.1021/es061710t, 2007.

Zander, R., Solomon, S., Mahieu, E., Goldman, A., Rinsland, C. P., Gunson, M. R., Abrams, M. C., Chang, A. Y., Salawitch, R. J., Michelsen, H. A., Newchurch, M. J., and Stiller, G. P.: Increase of stratospheric carbon tetrafluoride $\left(\mathrm{CF}_{4}\right)$ based on ATMOS observations from space, Geophys. Res. Lett., 23, 23532356, 1996.

Zhihong, W., Seidel, S., Atkinson, M., and Agyemang-Bonsu, W.: Chapter 3.3, Industrial Processes, PFC Emissions from Aluminium Production, in: IPCC Good Practice Guidance and Uncertainty Management in National Greenhouse Gas Inventories, IGES, Hayama, Japan, 2001.

Zhou, D. K., Bingham, G. E., Anderson, G. P., and Nadile, R. M.: CIRRIS-1A measurements of stratospheric carbon tetrachloride $\left(\mathrm{CCl}_{4}\right)$ and carbon tetrafluoride $\left(\mathrm{CF}_{4}\right)$, Geophys. Res. Lett., 25, 325-328, 1998. 